\title{
Absolute quantification of mRNA using real-time reverse transcription polymerase chain reaction assays
}

\section{S A Bustin}

Academic Department of Surgery, St Bartholomew's and the Royal London School of Medicine and Dentistry, Queen Mary and Westfield College, London E1 1BB, UK; Email: s.a.bustin@mds.qmw.ac.uk

\begin{abstract}
The reverse transcription polymerase chain reaction (RT-PCR) is the most sensitive method for the detection of low-abundance mRNA, often obtained from limited tissue samples. However, it is a complex technique, there are substantial problems associated with its true sensitivity, reproducibility and specificity and, as a quantitative method, it suffers from the problems inherent in PCR. The recent introduction of fluorescence-based kinetic RT-PCR procedures significantly simplifies the process of producing reproducible quantification of mRNAs and promises to overcome these limitations. Nevertheless, their successful application depends on a clear understanding of the practical problems, and
\end{abstract}

careful experimental design, application and validation remain essential for accurate quantitative measurements of transcription. This review discusses the technical aspects involved, contrasts conventional and kinetic RT-PCR methods for quantitating gene expression and compares the different kinetic RT-PCR systems. It illustrates the usefulness of these assays by demonstrating the significantly different levels of transcription between individuals of the housekeeping gene family, glyceraldehyde-3-phosphate-dehydrogenase (GAPDH).

Fournal of Molecular Endocrinology (2000) 25, 169-193

\section{INTRODUCTION}

\section{Why mRNA quantification?}

Many cellular decisions concerning survival, growth and differentiation are reflected in altered patterns of gene expression and the ability to quantitate transcription levels of specific genes has always been central to any research into gene function (Zamorano et al. 1996). More recently, the emergence of molecular medicine has resulted in the increased use of techniques able to quantitate levels of RNA in clinical diagnostics. Such applications are wide-ranging and include procedures designed to quantify the regulation and expression of drug resistance markers in tumour cells (Ramachandran \& Melnick 1999), monitor responses to chemotherapy (Desjardin et al. 1999), measure the biodistribution and of transcription of geneencoded therapeutics (Fairman et al. 1999), provide a molecular assessment of tumour stage (Bustin \& Dorudi 1998), detect circulating tumour cells in cancer patients (Ghossein \& Rosai 1996), and detect bacterial (Hill 1996) and viral (Holodniy 1994) pathogens.

Four methods are in common use for the quantification of transcription: northern blotting and in situ hybridisation (Parker \& Barnes 1999), RNAse protection assays (Hod 1992, Saccomanno et al. 1992) and the reverse transcription polymerase chain reaction (RT-PCR) (Weis et al. 1992). A fifth method, cDNA arrays, is still limited in its use by cost considerations (Bucher 1999). Northern analysis is the only method providing information about mRNA size, alternative splicing and the integrity of RNA samples. The RNAse protection assay is most useful for mapping transcript initiation and termination sites and intron/exon boundaries, and for discriminating between related mRNAs of similar size, which would migrate at similar positions on a northern blot. In situ hybridisation is the most complex method of all, but is the only one that allows localisation of transcripts to specific cells within a tissue. The main limitation of these three 
techniques is their comparatively low sensitivity (Melton et al. 1984).

RT-PCR is an in vitro method for enzymatically amplifying defined sequences of RNA (Rappolee et al. 1988) and permits the analysis of different samples from as little as one cell in the same experiment. It is the most sensitive and the most flexible of the quantification methods (Wang \& Brown 1999) and can be used to compare the levels of mRNAs in different sample populations, to characterise patterns of mRNA expression, to discriminate between closely related mRNAs, and to analyse RNA structure. RT-PCR can also circumvent time-consuming and technically demanding cloning steps and generate reagents, such as full-length complementary DNA (cDNA) inserts for cloning (Borson et al. 1992), or arbitrarily primed enhanced sequence tag cDNA libraries (Neto et al. 1997).

The focus on maximising sensitivity has led to the development of ever-more complex procedures. Semi-nested (Wasserman et al. 1999), nested (Israeli et al. 1994, Soeth et al. 1996), and even three-step nested (Funaki et al. 1997, 1998) RT-PCR techniques increase the sensitivity, but compromise the specificity of the reaction (Henke et al. 1997). They increase the likelihood of contamination and of detection of false positives (Kwok \& Higuchi 1989) and are unable to distinguish genuine, low-level transcription from illegitimate transcription (Chelly et al. 1989).

\section{Basic considerations}

The RT-PCR is a complex assay (Fig. 1A) and all physical and chemical components of the reaction are interdependent. They must be considered carefully when optimising the specificity, sensitivity, reproducibility or fidelity of the reaction. Successful performance of the RT-PCR depends on a clear understanding of the primary aim of the assay. Specificity, sensitivity and reproducibility will be the most important qualitative characteristics for clinical diagnostic uses. Conversely, if the purpose of the experiment is mutation analysis, cloning or expression, fidelity will be the prime consideration.

As RNA cannot serve as a template for PCR, the first step in an RT-PCR assay is the reverse transcription of the RNA template into cDNA, followed by its exponential amplification in a PCR reaction. Usually, this involves the use of dedicated RNA- and DNA-dependent DNA polymerases, either in separate ('two-enzyme/two-tube') or in single ('two-enzyme/one-tube') reactions, as the use of dedicated enzymes with different properties allows for the customisation of individual RT-PCR assays. Separation of the RT and PCR steps has the advantage of generating a stable cDNA pool that can be stored virtually indefinitely. Alternatively, a single polymerase able to function both as an RNA and DNA-dependent DNA polymerase can be used in a 'one-enzyme/one-tube' reaction and minimises hands-on time in addition to the risk of contamination.

\section{Reverse transcription}

RNA transcripts can exhibit significant secondary structure that affects the ability of the RNAdependent DNA polymerase (reverse transcriptase, RT) to generate transcripts (Buell et al. 1978). This can affect RT-PCR quantification and should be minimised when comparing or quantifying diverse mRNA populations (Shimomaye \& Salvato 1989). The two commonly used RTs are avian myeloblastosis virus reverse transcriptase (AMV-RT) and Moloney murine leukaemia virus reverse transcriptase (MMLV-RT). AMV-RT is more robust than MMLV-RT (Brooks et al. 1995), retains significant polymerisation activity up to $55^{\circ} \mathrm{C}$ (Freeman et al. 1996) and can help eliminate problems associated with RNA secondary structure. In contrast, MMLV-RT and engineered derivatives (Kotewicz et al. 1988) have significantly less RNAse $\mathrm{H}$ activity than AMV-RT (Gerard et al. 1997). As even reduced RNAse $\mathrm{H}$ activity can interfere with the synthesis of long amplicons (DeStefano et al. 1991), MMLV-RT may be a better choice if the aim of the experiment is the amplification of full-length cDNA molecules.

The RT step can be primed using specific primers, random hexamers or oligo-d $\mathrm{T}$ primers, and the choice of primers requires careful consideration. The use of mRNA-specific primers decreases background priming, whereas the use of random and oligo-dT primers maximises the number of mRNA molecules that can be analysed from a small sample of RNA. Primers can cause marked variation in calculated mRNA copy numbers and, compared with specific downstream primers, random hexamers can overestimate mRNA copy numbers by up to 19-fold (Zhang \& Byrne 1999).

\section{Polymerase chain reaction}

In an analogous manner, the choice of thermostable DNA-dependent DNA polymerases is determined by the aims of the experiment. There is a wide choice of enzymes that differ in their processivity, fidelity, thermal stability and ability to read 


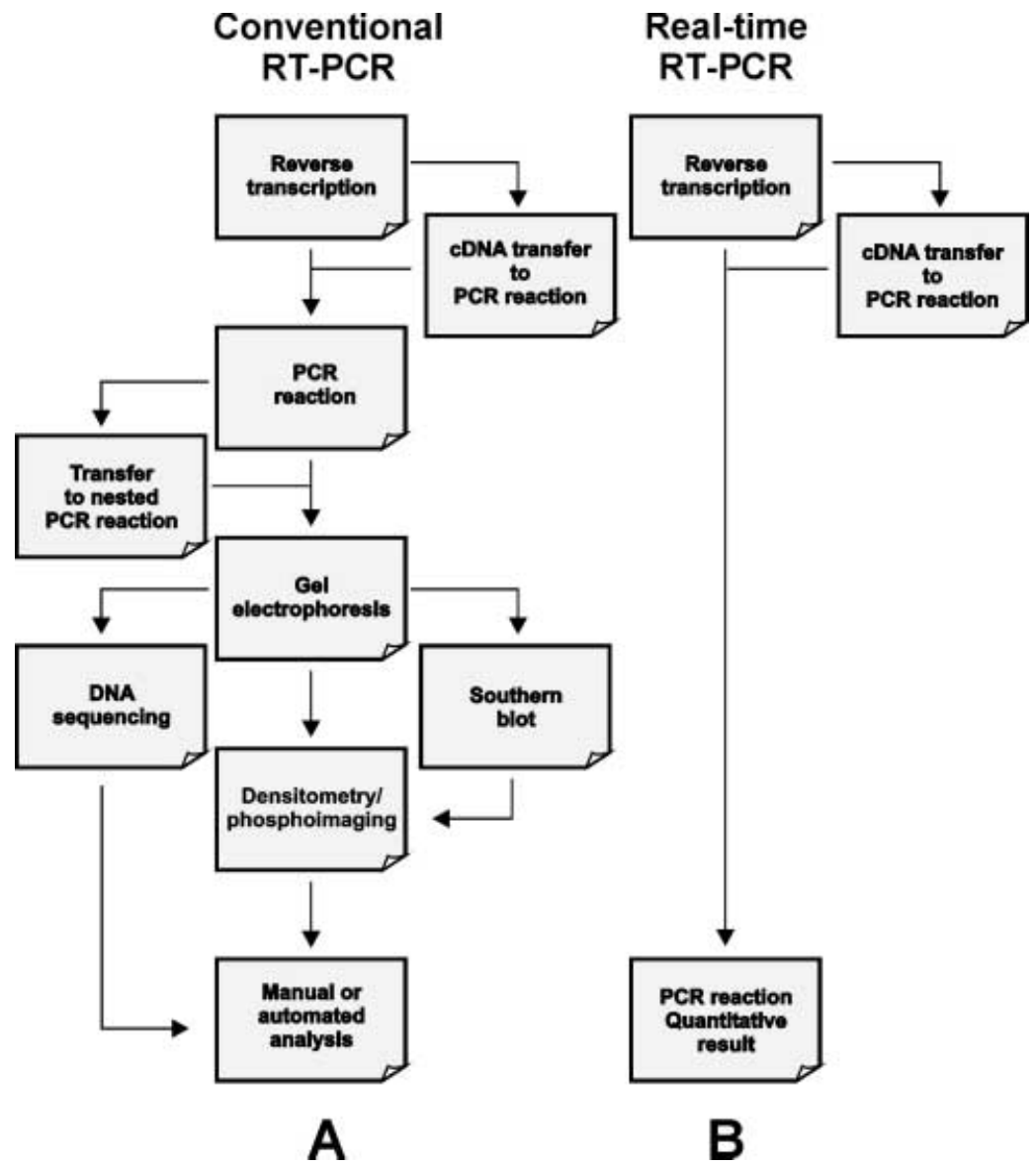

FIgure 1. RT-PCR quantification. (A) Conventional RT-PCR. The reaction can be carried out either with reverse transcriptase in a separate reaction, followed by transfer of some of the cDNA into a second reaction for the $\mathrm{PCR}$, or as a combined one-tube reaction with a heat-stable DNA-dependent polymerase. The former may be more sensitive and has the advantage of generating a cDNA reservoir that can be re-used repeatedly to carry out further PCR reactions. The latter has the advantages of speed, simplicity and less chance of contamination. Maximum sensitivity is achieved using a nested PCR reaction; however, this is frequently at the cost of reduced specificity. Gel electrophoresis is common to all procedures, but Southern blotting and/or DNA sequencing may be required to confirm the identity of the amplicon. A final step involves some method for quantitating the bands on the gel. (B) Real-time RT-PCR. The reverse transcription reaction is carried out as described above. All subsequent steps are carried out by the thermal cycler/detector and a quantitative result is processed by computer.

modified triphosphates such as deoxyuridine and deoxyinosine in the template strand (Adams \& Kelly 1994, Perler et al. 1996). The most commonly used enzyme, Taq DNA polymerase, has a $5^{\prime}-3^{\prime}$ nuclease activity but lacks a $3^{\prime}-5^{\prime}$ proofreading exonuclease activity. This makes its use less advisable when fidelity is the main consideration; instead, proofreading exonucleases such as Vent and Deep Vent (New England Biolabs, Beverly, MA,
USA) or Pfu (Stratagene, La Jolla, CA, USA) should be used (Cline et al. 1996), although their Michaelis constants $\left(K_{\mathrm{m}}(\mathrm{DNA})\right)$ can differ by more than two orders of magnitude from that of Taq polymerase, which has a direct effect on the effective primer annealing temperature. As the specificity of the PCR step is crucially dependent on the primers (Zhang \& Byrne 1999), reaction conditions must be re-optimised every time a different enzyme is used 
and results obtained may not be directly comparable. Furthermore, the proofreading activity can lead to primer degradation ('nibbling') from the 3' end. The rate of degradation is dependent on the length of the primer: a 60 mer is degraded much faster than a 30 mer. This can be counteracted by synthesising primers with phosphorothioate linkages on the last two $3^{\prime}$ bases, as this linkage renders the primers extendable but not degradable (de Noronha \& Mullins 1992).

In addition, $\mathrm{Mg}^{2+}$ and dNTP concentrations require strict control, because $\mathrm{Mg}^{2+}$ affects enzyme activity, and imbalanced dNTP mixtures will reduce polymerase fidelity (Eckert \& Kunkel 1991). In addition, $\mathrm{Mg}^{2+}$ increases the melting temperature $\left(T_{\mathrm{m}}\right)$ of double-stranded DNA, and forms soluble complexes with dNTPs to produce the actual substrate that the polymerase recognises. Therefore, high concentrations of dNTPs interfere with polymerase activity and affect primer annealing by reducing free $\mathrm{Mg}^{2+}$. In addition, the $K_{\mathrm{m}}$ (dNTP) values of different polymerases vary significantly and must be taken into consideration when planning an RT-PCR assay.

\section{One-enzyme RT-PCR}

In situations in which convenience is the main priority or the target RNA contains extensive secondary structure, it is advisable to use a single tube ('one-enzyme/one-tube') system utilising Thermus thermophilus (Tth) polymerase, a DNA polymerase with intrinsic RT, but no RNAse H, activity (Myers \& Gelfand 1991). This assay uses bicine buffers containing $\mathrm{Mn}^{2+}$ ions that are compatible with both RT and subsequent PCR (Chiocchia \& Smith 1997). This permits the RT reaction to be carried out at increased temperatures using primers with significantly higher $T_{\mathrm{m}}$, while reducing both hands-on time and the likelihood of introducing contaminants into reaction mixtures. There is also evidence that RT-PCR reactions using Tth polymerase may be more robust and resistant to inhibitors present in biological specimen (Poddar et al. 1998). The main drawbacks of this system are that: (i) because the sensitivity of $\mathrm{Tth}$ polymerase is two orders of magnitude lower than that of Taq polymerase (Grabko et al. 1996), this system is not as sensitive as two-enzyme procedures (Cusi et al. 1994, Leutenegger et al. 1999); (ii) the presence of $\mathrm{Mn}^{2+}$ ions reduces the fidelity of nucleotide incorporation (Beckman et al. 1985, Fromant et al. 1995); (iii) like Taq polymerase, Tth polymerase lacks a 3 ' -5 'exonuclease proofreading activity; and (iv) first-strand synthesis must be initiated from specific primers, rather than using random primers.
We have found that reducing the denaturation temperature to $92{ }^{\circ} \mathrm{C}$ can improve the sensitivity of the assay, probably because $\mathrm{T}$ th polymerase is somewhat less thermostable than Taq polymerase. However, for some templates, especially if they are long or $\mathrm{G} / \mathrm{C}$ rich, this reduction may results in lower amplification efficiencies, as incompletely melted DNA will mask primer and probe binding sites.

\section{QUANTIFICATION}

\section{RT-PCR quantification strategies}

Quantification of mRNA can be by semiquantitative or quantitative methods (Ferre 1992). Semi-quantitative RT-PCR results are typically generated by frequent sampling of the RT-PCR reaction mixture followed by dot-blot analysis (Montgomery \& Dallman 1997). This additional complexity does not lend itself to easy automation and, as the name implies, this method is at best semi-quantitative and its use should be avoided.

Quantitative procedures use non-competitive or, more commonly, competitive RT-PCR techniques (Wang et al. 1989, Vanden Heuvel et al. 1993). They depend on the spiking into the RNA samples before RT of known amounts of RT-PCR-amplifiable competitors that, ideally, should be synthetic RNA molecules. Noncompetitive RT-PCR refers to the co-amplification of the target with a second RNA molecule under reagent concentrations and conditions so that there is no competition between target and standard, and with which it shares neither the primer recognition sites nor any internal sequence (Reischl \& Kochanowski 1999). However, this means that quantification can be unreliable, as the efficiencies of both the RT and PCR steps are likely to vary even when monitoring relative changes of transcription within a sample (Ferre 1992). In addition, as standard RNA is added in a linear fashion within one order of magnitude of the target, noncompetitive RT-PCR requires some approximate knowledge of target amounts (Freeman et al. 1999).

In competitive RT-PCR, the internal standard shares the same primer recognition and internal sequences with the primary target, leading to competition for reagents. Because they are virtually identical, both should be amplified with the same efficiency and their amplicons can be distinguished by the addition of a restriction enzyme site to the standard (Gilliland et al. 1990, Becker-Andre 1993) or by varying its size (Gilliland et al. 1992, Scheuermann \& Bauer 1993). A series of PCR tubes containing the target are spiked with serial dilutions 
of known copy numbers of the internal standard. The greater the concentration of the internal standard, the more likely it is that the primers will bind and amplify it, rather than the target. After gel electrophoresis, a comparison of the intensities of ethidium-bromide-stained standard and target amplicons allows target quantification (Raeymaekers 1999). However, this may still not result in absolute quantification because, for example, stable differences in amplification efficiency between target and competitor will remain undetected (Raeymaekers 1993). There have been numerous attempts to enhance the accuracy of quantification by improving RNA isolation (Fernandez et al. 1997), reaction conditions (Corey et al. 1997), and detection methods (Borson et al. 1998, Hayward et al. 1998, Marchand et al. 1999). In spite of, or perhaps because of, this, competitive quantification procedures are, without exception, labour- and reagent-intensive.

The minimum error in competitive RT-PCR reactions is approximately $10 \%$, even when competitor and target are present in equal amounts (Souaze et al. 1996), and it is usually significantly greater. There are several reasons for this. (i) The amplification efficiencies of exogenous competitor, which must be synthesised for each gene being quantified, are not always equivalent. (ii) Competitor RNA must be transcribed in vitro, which adds an additional enzymatic step; furthermore, once transcribed it may degrade during long-term storage. (iii) Heteroduplex formation between the nearly identical standard and target can result in variable sensitivity and accuracy (Henley et al. 1996); use of DNA competitors with primer binding sites flanking unrelated internal sequences (mimics) (Siebert \& Larrick 1993) eliminates that problem, but causes new ones. (iv) The quantification of competitor fragments generated by restriction digestion requires the dilution of $\mathrm{PCR}$ products before digestion, introducing one source of error; a second source of error is the restriction digest itself, as it may not completely digest the competitor. (v) Finally, the technique is not amenable to high throughput because, typically, for each unknown target a large series of reactions with different competitor:target ratios has to be run (Raeymaekers 1993); therefore, conventional RTPCR-based procedures are not suitable for routine use, especially when several targets from many samples are being quantified.

\section{Instrumentation}

The application of fluorescence techniques to the RT-PCR, together with suitable instrumentation capable of combining amplification, detection and quantification, has led to the development of kinetic RT-PCR methodologies that are revolutionising the possibilities for quantitating nucleic acids (Orlando et al. 1998). There are three competing instruments on the market; all three are run as closed-tube systems and quantification requires no postamplification manipulation. This avoids problems of contamination, results in short turn-around times for data acquisition and analysis and minimises hands-on time (Fig. 1B). The entire process, starting at the RT and ending with full quantification, is automated (Fig. 2), which makes these instruments ideally suited for high-throughput screening applications (Martell et al. 1999, Wattjes et al. 2000).

The ABI Prism 7700 (Perkin-Elmer-Applied Biosystems, Foster City, CA, USA) contains a built-in thermal cycler with 96 -well positions, and is able to detect fluorescence between $500 \mathrm{~nm}$ and $660 \mathrm{~nm}$. Fluorescence is induced during the RTPCR by distributing laser light to all 96 samples contained in thin-walled reaction tubes via a multiplexed array of optical fibres. The resulting fluorescent emission returns via the fibres and is directed to a spectrograph with a charge-coupled device (CCD) camera. Because each well is irradiated sequentially, the dimensions of the CCD array can be used for spectral resolution of the fluorescent light. This instrument can be used for assays based on DNA-binding dyes, molecular beacons and hydrolysis probes. RT-PCR reactions typically take $2 \mathrm{~h}$ to complete. Its description by the manufacturer as a real-time technique is not strictly correct as, unlike competing systems, the progress of the RT-PCR reaction can currently be analysed only after termination of the amplification run.

The Lightcycler (Roche Molecular Biochemicals, Mannheim, Germany) performs the RT-PCR in small-volume glass capillary tubes, contained within a rotor-like carousel, that are heated and cooled in an airstream (Wittwer et al. 1989). The carousel is rotated past a blue light-emitting diode, and fluorescence is read by three photodetection diodes with different wavelength filters that allow the use of spectrally distinct fluorescent probes (Wittwer et al. 1997b). The performance of the Lightcycler in terms of sensitivity and specificity is equal to that of Taqman (Nitsche et al. 1999). In addition to being able to use assays based on DNA-binding dyes, hydrolysis probes and molecular beacons, it can be used for dual hybridisation probes. Up to 32 reactions are typically carried out in 5-20 $\mu 1$ volumes (Wittwer et al. 1990) and RT-PCR reactions are completed in less than $20 \mathrm{~min}$ (Wittwer \& Garling 1991). The Lightcycler a truly 


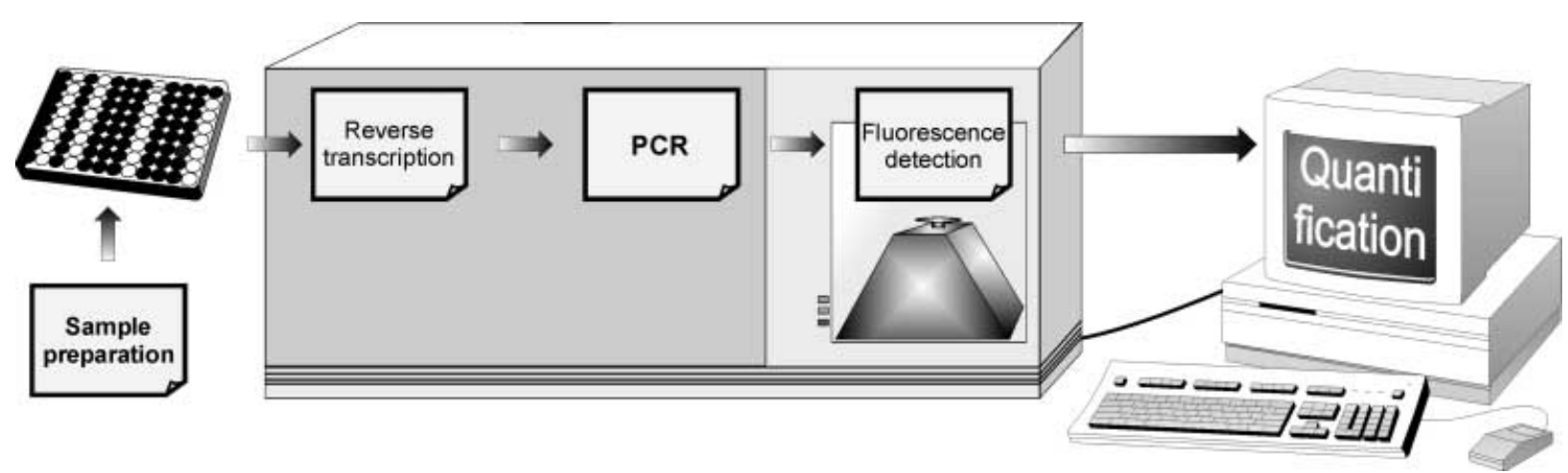

FIGURE 2. The principle of Taqman RT-PCR. Amplification is performed in closed, optical tubes of a 96-well microplate that is placed in a combined thermal cycler/detector, the ABI 7700. A laser is directed to each of the 96 sample wells, and the fluorescence emission data for each sample are collected once every few seconds as the PCR products are being generated. The fluorescence is spectrally analysed, allowing the simultaneous use of more than one spectrally distinct fluorescent probe. The starting copy number is determined by monitoring when PCR product is first detected - the higher the starting copy number of the target, the sooner a significant increase in fluorescence is observed. The data are fed to a computer, which analyses and displays the results, eliminating the need for post-PCR processing.

'real-time' technique, and the fluorescence readings taken at every cycle of the PCR reaction are displayed immediately after each measurement, allowing amplification runs to be terminated or extended, as appropriate, during individual runs.

Biorad Instruments have recently launched an optical module that fits their standard thermal cycler and transforms it into a real-time RT-PCR system. This instrument is capable of generating and detecting a wider range of excitation frequencies than either the ABI 7700 or the Lightcycler. At present, it can monitor up to four different fluorescent reporters at any one time and can be used for any one of of the alternative fluorescent RT-PCR strategies. Furthermore, unlike the ABI 7700 which scans its 96 samples sequentially, this instrument can scan up to 96 samples simultaneously, with a sampling frequency that can be defined by the user.

\section{Chemistries}

There are currently four competing techniques available that detect amplified product with about the same sensitivity (Wittwer et al. 1997a). They use fluorescent dyes and combine the processes of amplification and detection of an RNA target to permit the monitoring of $\mathrm{PCR}$ reactions in real-time during the PCR; their high sensitivity eliminates the need for a second-round amplification, and decreases opportunities for generating false-positive results (Morris et al. 1996). The simplest method uses fluorescent dyes that bind specifically to double-stranded-DNA. The other three rely on the hybridisation of fluorescence-labelled probes to the correct amplicon. The methods differ in their specificity, although at later amplification cycles all can show artefacts that do not correlate to specific product accumulation. As amplicon detection in the molecular beacon, hydrolysis and hybridisation probe assays depends on successful hybridisation of the probe, these RT-PCR procedures obviate the need for post-PCR Southern analysis or sequencing to confirm the identity of the amplicon.

\section{Molecular beacons}

Molecular beacons (Stratagene) are DNA hybridisation probes that form a stem-and-loop structure; the loop portion of the molecule is complementary to the target nucleic acid molecule and the stem is formed by the annealing of complementary arm sequences on the ends of the probe sequence (Tyagi \& Kramer 1996) (Fig. 3). A fluorescent marker is attached to the end of one arm and a quencher is attached to the end of the other arm. The quencher is a non-fluorescent chromophore that dissipates the energy that it receives from the fluorophore as heat. In solution, free molecular beacons adopt a hairpin structure and the stem keeps the arms in close proximity, resulting in efficient quenching of the fluorophore. When molecular beacons encounter a complementary target at the annealing temperature, they undergo a conformational transition that forces the stem apart and results in the formation of a probe/target hybrid that is longer and more stable than the stem (Bonnet et al. 1999). This separates the fluorophore and the quencher, leading to the 


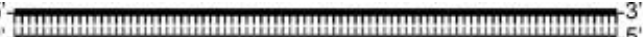

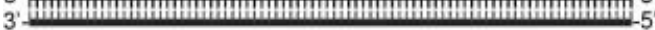

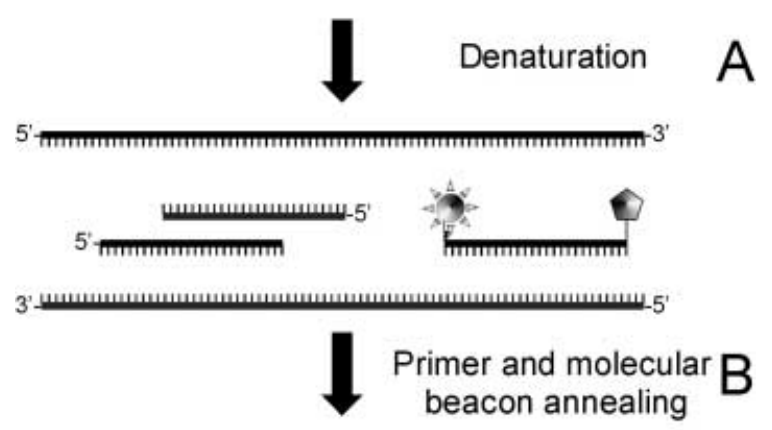

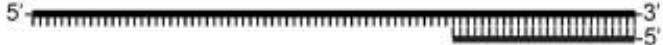

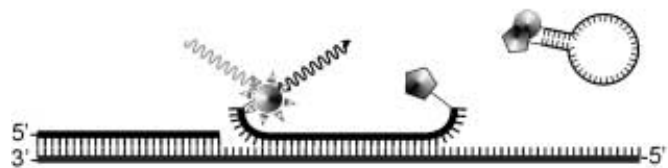

1 reserestaten $\mathrm{C}$

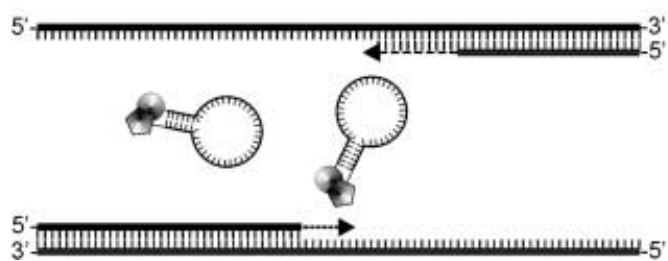

FIGURE 3. The molecular beacons assay. Molecular beacons are designed to be complementary to a sequence in the middle of the expected amplicon. The RT step has been omitted. (A) During the denaturation step, the molecular beacons assume a random coil configuration and fluoresce. (B) As the temperature is decreased to allow annealing of the primers, stem hybrids form rapidly, preventing fluorescence. However, in the presence of target, molecular beacons also bind to the amplicons and generate fluorescence. (C) When the temperature is increased for the primer extension step, the molecular beacons dissociate from their targets, and fluorescence is again quenched. A new hybridisation takes place in the annealing step of every cycle, and the intensity of the resulting fluorescence indicates the amount of accumulated amplicon at the end of the previous cycle.

restoration of fluorescence, which can be detected, whereas any free molecular beacons remain closed and non-fluorescent. If the target DNA sequence does not exactly match the molecular beacon sequence, hybridisation and fluorescence will not occur. This is because the thermodynamic properties of the molecular beacons favour the formation

www.endocrinology.org of a hairpin form rather than continued hybridisation to a less than perfectly matched target sequence. Molecular beacons require the use of a spectrofluorimetric thermal cycler for real-time detection, but can also be used in an endpoint assay using a fluorimeter. The specificity of this system is such that it can readily detect single nucleotide differences (Giesendorf et al. 1998, Marras et al. 1999), something that can be difficult to achieve with the Taqman system.

Molecular beacons can also be used in non-PCR amplification assays that utilise isothermal nucleic acid amplification schemes (Guatelli et al. 1990, Tyagi et al. 1996) such as strand-displacement amplification (Walker et al. 1992), nucleic acid sequence-based amplification (Leone et al. 1998), and rolling-circle amplification (Lizardi et al. 1998).

The main drawback with molecular beacons is associated with the design of the hybridisation probe. Optimal design of the molecular beacon stem is crucial, as the molecular beacon may fold into alternate conformations that do not place the fluorophore in the immediate vicinity of the quencher, resulting in a sub-population that is not quenched well and in large background signals. Alternatively, if the stem of a molecular beacon is too strong, it can interfere with the hybridisation and the fluorescence of the beacon annealed to its target may be incompletely restored. Therefore, accurate thermal denaturation profiles to determine their melting characteristics must be established for each molecular beacon and different target sequences will have to be matched with different stem sequences.

\section{DNA-binding dyes}

This method (Fig. 4A) involves detection of the binding of a fluorescent dye (SYBR Green) to DNA (Morrison et al. 1998). The unbound dye exhibits little fluorescence in solution, but during elongation increasing amounts of dye bind to the nascent double-stranded DNA. When monitored in realtime, this results in an increase in the fluorescence signal that can be observed during the polymerisation step, and that falls off when the DNA is denatured. Consequently, fluorescence measurements at the end of the elongation step of every PCR cycle are performed to monitor the increasing amount of amplified DNA. This method obviates the need for target-specific fluorescent probes, but its specificity is determined entirely by its primers. As the presence of any double-stranded DNA generates fluorescence, this assay is no more specific than conventional RT-PCR. However, additional specificity and RT-PCR product verification can be 


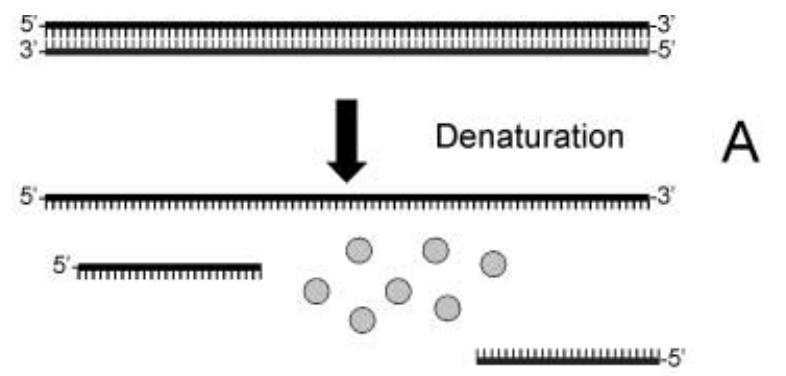

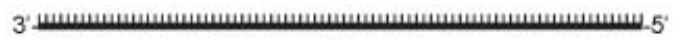
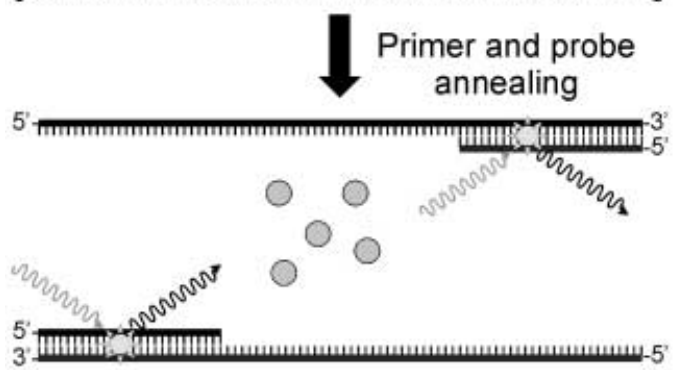

I Poymenisation
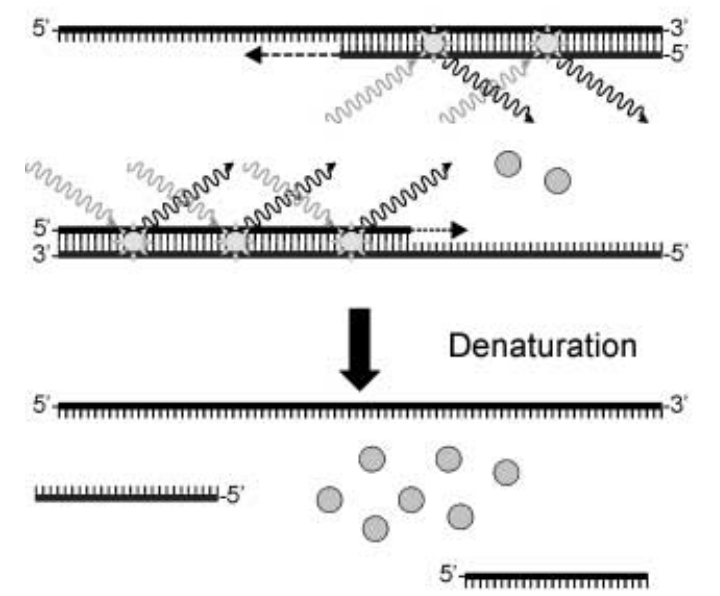
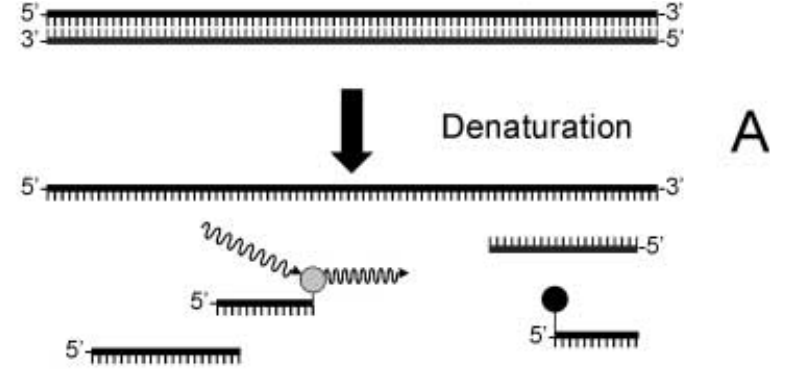

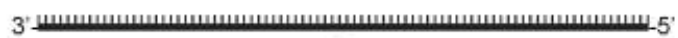

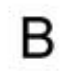

Primer and probe annealing

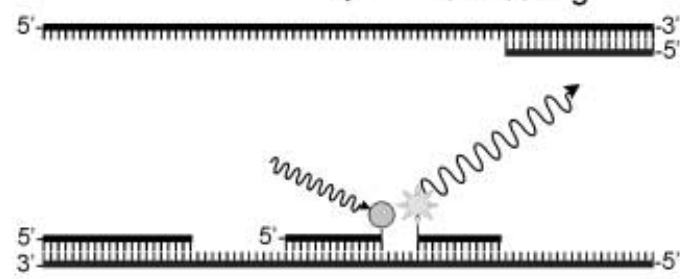

B 5
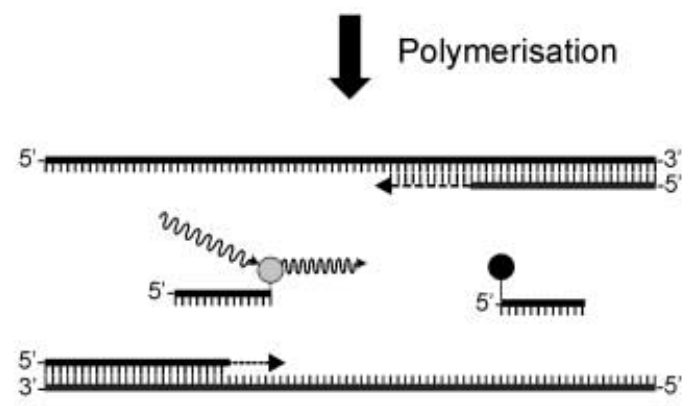

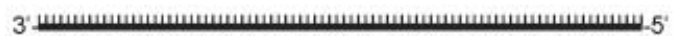

FIGURE 4. The Lightcycler assay. Left: Dye incorporation method. (A) During denaturation, unbound SYBR Green I dye exhibits little fluorescence. (B) At the annealing temperature, a few dye molecules bind to the double-stranded primer/target, resulting in light emission upon excitation. (C) During the polymerisation step, more and more dye molecules bind to the newly synthesised DNA, and the increase in fluorescence can be monitored in real-time. (D) On denaturation, the dye molecules are released and the fluorescence signal returns to background. Right: Hybridisation probe method. The RT step has been omitted. (A) During the denaturation step, both hybridisation probes remain in solution and separate. Any emission from fluorescein is at $530 \mathrm{~nm}$, and is disregarded by the detector. (B) During the annealing step, the probes hybridise in a head-to-tail arrangement, the two dyes come in close proximity and the emitted energy excites the second dye, which emits red fluorescent light at a longer wavelength. (C) At the polymerisation temperature, both probes return into solution and any emissions from fluorescein are ignored. 
achieved by plotting fluorescence as a function of temperature to generate a melting curve of the amplicon (Ririe et al. 1997). This is done by slowly increasing the temperature above the $T_{\mathrm{m}}$ of the amplicon and measuring the fluorescence. As the $T_{\mathrm{m}}$ of the amplicon depends markedly on its nucleotide composition, it is possible to identify the signal obtained from the correct product. A characteristic melting peak at the melting temperature $\left(T_{\mathrm{m}}\right)$ of the amplicon will distinguish it from amplification artefacts that melt at lower temperatures in broader peaks. A second drawback of this procedure is that multiple dye molecules bind to a single amplified molecule and, consequently, the amount of signal generated after irradiation is dependent on the mass of double-stranded DNA produced in the reaction. Assuming the same amplification efficiencies, amplification of a longer product will generate more signal than a shorter one. If amplification efficiencies are different, quantification will be even more inaccurate. This is in contrast to the use of fluorogenic probes (see below), in which the signal from a single fluorophore is observed for each amplified molecule synthesised, regardless of its length.

\section{Hybridisation probes}

This method uses two hybridisation probes to maximise specificity (Wittwer et al. 1997a) (Fig. 4B). One of the probes carries at its $3^{\prime}$ end a fluorescein donor, which emits green fluorescent light when excited by the Lightcycler's light source. Its emission spectrum overlaps the excitation spectrum of an acceptor fluorophore that is attached to the $5^{\prime}$ end of the second probe. This probe must be blocked at its $3^{\prime}$ end to prevent its extension during the annealing step. Excitation of the donor results in fluorescence resonance energy transfer to the acceptor and the emission of red fluorescent light. In solution, the two dyes are apart, and because the energy transfer depends on the spacing between the two dye molecules, only background fluorescence is emitted by the donor. After the denaturation step, both probes hybridise to their target sequence in a head-to-tail arrangement during the annealing step. This brings the two dyes in close proximity to one another and the fluorescein can transfer its energy at high efficiency. The intensity of the light of longer wavelength emitted by the second dye is measured, with increasing amounts of measured fluorescence proportional to the amount of DNA synthesised during the PCR reaction. A fluorescent signal is detected only as a result of two independent probes hybridising to their correct target sequence. This increases specificity and generates additional flexibility for probe design. Furthermore, as the probes are not hydrolysed, fluorescence is reversible and allows the generation of melting curves (see below).

\section{Hydrolysis probes}

The Taqman assay (Perkin-Elmer-Applied Biosystems) utilises the $5^{\prime}$-nuclease activity of the DNA polymerase to hydrolyse a hybridisation probe bound to its target amplicon. It usually utilises either Taq or Tth polymerase, but any enzyme with an equivalent $5^{\prime}$-nuclease activity properties (e.g. Tfl), can be used (Gut et al. 1999). After the reverse transcription step (Fig. 5A), successful quantification requires the annealing of three oligonucleotides to the DNA. Two template-specific primers define the endpoints of the amplicon and provide the first level of specificity (Fig. 5B). Problems associated with DNA contamination are minimised by choosing primers that span at least one intron of the genomic sequence. The additional specificity of this assay is provided by the use of a third oligonucleotide probe that hybridises to the amplicon during the annealing/extension phase of the PCR (Fig. 5C). The probe contains a fluorescent reporter dye at its $5^{\prime}$ end, the emission spectrum of which is quenched by a second fluorescent dye at its $3^{\prime}$ end. If no amplicon complementary to the probe is amplified during the PCR, the probe remains unbound. As the $5^{\prime}$-exonuclease activity of Taq and Tth polymerase is double-strand-specific (Heid et al. 1996), unbound probe remains intact and no reporter fluorescence is detected. Conversely, if the correct amplicon has been amplified, the probe can hybridise to that amplicon after the denaturation step. It remains hybridised while the polymerase extends the primers until it reaches the hybridised probe, when it displaces its $5^{\prime}$ end to hold it in a forked structure. The enzyme continues to move from the now free end to the bifurcation of the duplex, where cleavage takes place (Lyamichev et al. 1993). This separates the reporter and quencher dyes and releases quenching of reporter fluorescence emission (Fig. 5D,E). The largest fluorescence signal is obtained when the two labels are at the extreme $5^{\prime}$ and $3^{\prime}$ ends of the probe, probably because of more efficient cleavage by the polymerase (Livak et al. 1995).

As the polymerase will cleave the probe only while it remains hybridised to its complementary strand, the temperature conditions of the polymerisation phase of the PCR must be adjusted to ensure probe binding. Most probes have a $T_{\mathrm{m}}$ of around $70{ }^{\circ} \mathrm{C}$; therefore, the Taqman system uses a combined annealing and polymerisation step at 


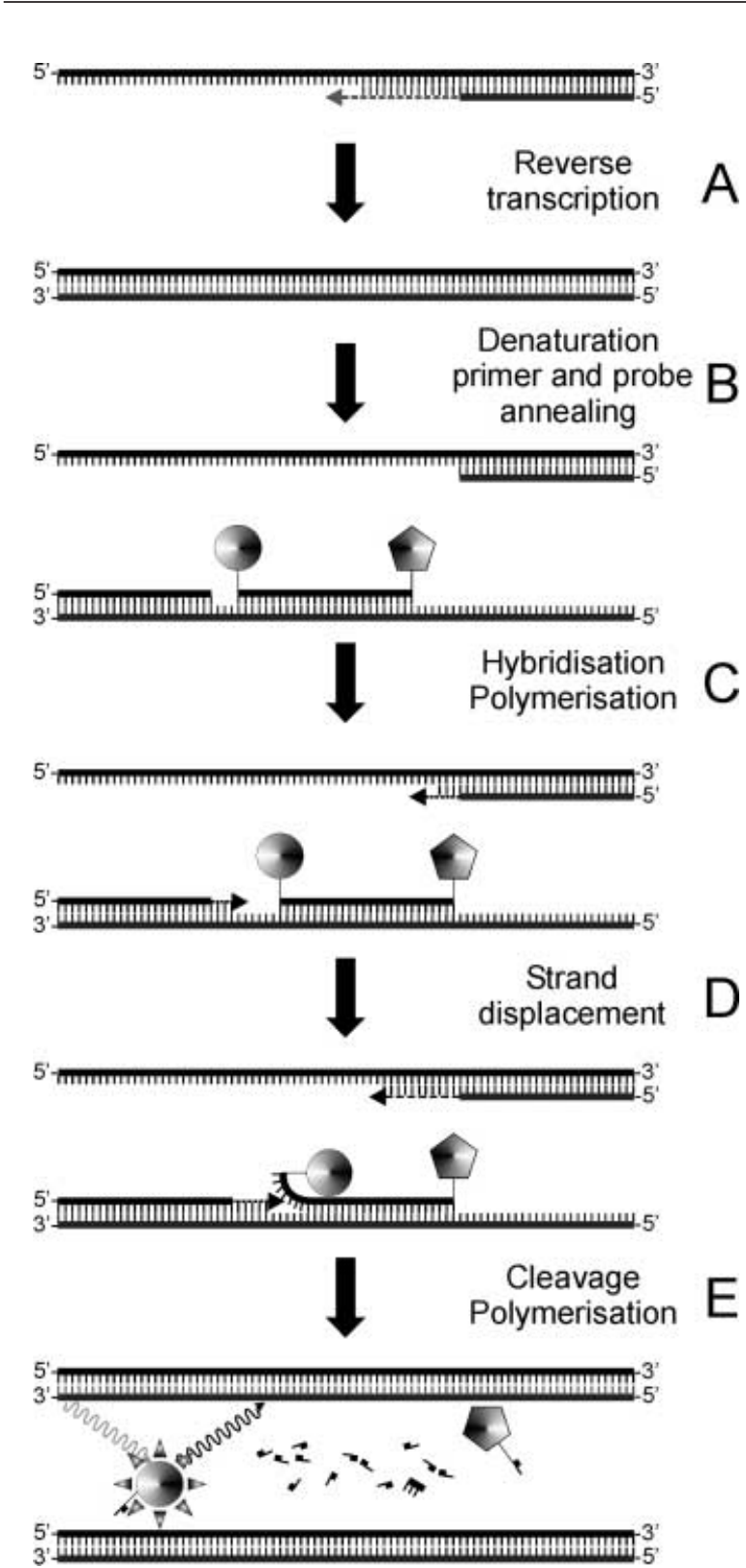

FIGURE 5. The Taqman assay. Three parameters affect the performance of the $5^{\prime}$-nuclease assay: the quenching of the intact probe, its hybridisation efficiency and the efficiency of cleavage by the polymerase. (A) The RT step synthesises a cDNA copy of the mRNA. (B) After denaturation, primers and probe anneal. The proximity of the two dyes quenches the signal from the fluorescent dye at the $5^{\prime}$ end of the probe. (C) Polymerisation proceeds at the same temperature as the annealing step. (D) The polymerase displaces and hydrolyses the labelled probe. (E) The fluorescent dye is released from its proximity to the quencher, and fluorescence is detected. This signal is directly proportional to the number of molecules present at the end of the previous or beginning of the current cycle.

$60-62{ }^{\circ} \mathrm{C}$. This ensures that the probe remains bound to its target during the primer extension step. It also ensures maximum $5^{\prime}-3^{\prime}$ exonuclease activity of the Taq and Tth DNA polymerases (Tombline et al. 1996). However, it also reduces the processivity of the polymerases, which are required to function at sub-optimal temperatures. For longer amplicons, this may require a longer annealing/polymerisation step and/or increased $\mathrm{Mn}^{2+}$ or $\mathrm{Mg}^{2+}$ concentration to stabilise probe binding. It also makes this system potentially less efficient and flexible than other realtime systems, especially when mutation-specific RT-PCR is attempted.

\section{Amplicon design}

The optimal amplicon length for real-time RTPCR is less than $100 \mathrm{bp}$, and we aim to generate amplicons no longer than $80 \mathrm{bp}$, but have used the Taqman system to detect amplicons as long as $400 \mathrm{bp}$ (Bustin et al. 1999). Shorter amplicons amplify more efficiently than longer ones and are more tolerant of reaction conditions. This is because they are more likely to be denatured during the 92-95 ${ }^{\circ} \mathrm{C}$ step of the PCR, allowing the probes and primers to compete more effectively for binding to their complementary targets. As the extension rate of Taq polymerase is between 30 and 70 bases/ second (Jeffreys et al. 1988), it also means that polymerisation times as short as $15 \mathrm{~s}$ are sufficient to replicate the amplicon, making amplification of genomic DNA contaminants less likely and reducing the time it takes to complete the assay. The length of primers and probe required to generate a specific product defines the minimum practical length of the amplicon, which in our hands is $63 \mathrm{bp}$ (Bustin et al. 1999).

\section{Primer design}

Primers should bind to separate exons to avoid false positive results arising from amplification of contaminating genomic DNA. If the intron/exon boundaries are unknown, or when targeting an intron-less gene, it is necessary to treat the RNA sample with RNAse-free DNAse. Use of $\mathrm{Mn}^{2+}$ rather than $\mathrm{Mg}^{2+}$ minimises any problems caused by amplification of re-annealed DNA fragments (Bauer et al. 1997). Primer (and probe) selection is based on estimated $T_{\mathrm{m}}$, the desire for small amplicon size and the location of the probe. They must be designed to very exacting specifications and the Taqman system provides its own primer/probe design program, Primer Express. The current version usually generates appropriate primer/probe sets, but it contains several bugs that can make 
primer design difficult, and requires manual fine-tuning. There are several alternative software tools available, with the most useful ones calculating $T_{\mathrm{m}}$ thermodynamically using the nearest-neighbour algorithm (Rychlik et al. 1990) - for example, OLIGO (Molecular Biology Insights, Cascade, CO, USA, http://oligo.net) or the online oligonucleotide $T_{\mathrm{m}}$ calculator (http://alces.med.umn.edu/rawtm. html). Recently, a program has been developed for $T_{\mathrm{m}}$ calculations of matched and mismatched probes designed to run on Microsoft Excel (Schutz \& von Ahsen 1999) and is available for academic users as freeware from http://server1.medikc.med. uni-goettingen.de/meltcalc.htm. The optimal length for single-stranded primers is about 15-20 bases, and the G/C content should be between $20 \%$ and $70 \%$. Their $T_{\mathrm{m}}$ should not differ by more than $1-2{ }^{\circ} \mathrm{C}$, with minimum and maximum $T_{\mathrm{m}}$ of $58{ }^{\circ} \mathrm{C}$ and $60{ }^{\circ} \mathrm{C}$, respectively, for Taqman primers. Molecular beacons- and hybridisation probeassociated primers can have a wider range of $T_{\mathrm{m}}$, but the $T_{\mathrm{m}}$ of any one pair should be similar. Primers are generally used in the 50-200 nM range. Too great a primer concentration may promote mispriming and accumulation of non-specific product. Too low a primer concentration is probably less of a problem for real-time assays, as target copy numbers will have been calculated well before the primer supply is exhausted. Non-specific priming can be minimised by selecting primers that have only one or two G/Cs within the last five nucleotides at the $3^{\prime}$ end. This relative instability at their $3^{\prime}$ ends makes them less likely to hybridise transiently, and available for non-specific extension by the DNA polymerase.

\section{Probe design}

The optimum concentration of fluorigenic probes depends on background fluorescence in addition to primer concentration. The fluorescence of nonhybridised molecular beacons and hybridisation probes is quenched more efficiently than is the fluorescence of uncleaved hydrolysis probes, resulting in significantly reduced background fluorescence and enhanced ability to distinguish the fluorescence of hybridised molecular beacon and hybridisation probes. Probe concentration is usually in the $100 \mathrm{nM}$ range and they must compete for binding to their target with the amplification primers, which are present in a greater concentration. As amplification primers are extended as soon as they bind to their targets, the hybridisation target sequence is rapidly masked with newly synthesised DNA. Therefore, the $T_{\mathrm{m}}$ of the probes must be significantly greater (approximately $10{ }^{\circ} \mathrm{C}$ ) than that of the primers, to ensure that they hybridise before the primers. The fluorescence of hybridisation probes is directly correlated to probe hybridisation, hence they must remain hybridised during the annealing step. Conversely, the fluorescence of exonuclease probes is correlated with probe hydrolysis, and they must be available for cleavage during the polymerisation step, to allow fluorescence measurement.

An additional requirement of the twohybridisation-probe system is that the target sequence should be located towards the $3^{\prime}$ end of the amplicon, close to the reverse primer-binding site on the opposite strand. As fluorescence is measured during the annealing phase, this arrangement allows time for the measurement to be made before the probes are displaced by the polymerase. Paired probes used for quantification should have equal $T_{\mathrm{m}}$, whereas for mutational analysis the $T_{\mathrm{m}}$ of the sensor probe should be less than that of the anchor probe. This ensures that the sensor probe controls the generation of the fluorescent signal.

Most of our probes are about 30 bases in length, and we aim for a $\mathrm{G} / \mathrm{C}$ content of around $50 \%$. This ensures good specificity and a $T_{\mathrm{m}}$ high enough to be useful under PCR conditions. It also minimises the potential for inter- or intramolecular complementarity, which can interfere with the PCR reaction. The probes should not overlap with, or have sequence complementarity with either of the primers, and Taqman probes should not contain a $G$ at their $5^{\prime}$ ends, because such an arrangement quenches reporter fluorescence, even after cleavage.

\section{Threshold cycle}

The concept of the threshold cycle $\left(C_{t}\right)$ is at the heart of accurate and reproducible quantification using fluorescence-based RT-PCR (Higuchi et al. 1993). Fluorescence values are recorded during every cycle and represent the amount of product amplified to that point in the amplification reaction. The more template present at the beginning of the reaction, the fewer number of cycles it takes to reach a point in which the fluorescent signal is first recorded as statistically significant above background (Gibson et al. 1996). This point is defined as the $\mathrm{C}_{\mathrm{t}}$, and will always occur during the exponential phase of amplification. Therefore, quantification is not affected by any reaction components becoming limited in the plateau phase, which results in a systematic bias against the more abundant templates and makes any quantification based on measurements of overall product yield intrinsically unreliable. 
The reporter signal is normalised to the fluorescence of an internal reference dye (Taqman) or between the three dyes (Lightcycler), to allow for corrections in fluorescent fluctuations caused by changes in concentration or volume, and a $C_{t}$ value is reported for each sample. This value can be translated into a quantitative result by constructing a standard curve.

\section{Standard curves}

Standard curves using fluorescence are easily generated, thanks to the linear response over a large dynamic range. Quantification of mRNA transcription can be either relative or absolute. Relative quantification determines the changes in steadystate transcription of a gene and is often adequate. A relative standard consists of a sample, the calibrator, which is used to create a dilution series with arbitrary units. The calibrator can be any nucleic acid, as long as its concentration and length of amplicon are known. During the RT-PCR assay, the target $\mathrm{C}_{t}$ is compared directly with the calibrator $C_{t}$ and is recorded as containing either more or less mRNA. In contrast, absolute quantification of transcription allows the precise determination of copy number per cell, total RNA concentration, or unit mass of tissue. It requires the construction of an absolute standard curve for each individual amplicon to ensure accurate reverse transcription and PCR amplification profiles.

There are two ways to prepare an absolute standard curve. The first method involves subcloning the amplicon behind a T7 or SP6 RNA polymerase promoter in a plasmid vector. An in vitro-transcribed sense RNA transcript is generated, the sample is digested with RNAse-free DNAse and the RNA is quantitated accurately. It is important to ensure that the standard RNA template is a single, pure species free from DNA contamination. We take triplicate measurements of its concentration on a spectrophotometer such as the Genequant II (Amersham Pharmacia Biotech, Little Chalfont, UK) and convert the absorbance to a 'target copy number per $\mu \mathrm{g}$ RNA'. The standard curve is generated by performing three independent serial dilutions of the RNA standard and assaying each dilution in duplicate, together with positive and negative control reactions. To maximise accuracy, the dilutions should be made over the range of copy numbers that include the amount of target mRNA expected in the experimental RNA samples. The high and low $\mathrm{C}_{\mathrm{t}}$ values are discarded to correct for pipetting error and the remaining four values are averaged to give the final $C_{t}$ value for that dilution. The $\mathrm{C}_{t}$ value is inversely proportional to the log of the initial copy number (Higuchi et al. 1993). Therefore, a standard curve is generated by plotting the $\mathrm{C}_{t}$ values, with $95 \%$ confidence intervals, against the logarithm of the initial copy numbers. The copy numbers of experimental RNAs can be calculated after real-time amplification from the linear regression of that standard curve.

We have found that the second method - use of single-stranded sense-strand oligodeoxynucleotides is an acceptable alternative to the T7-RNA polymerase-generated standard amplicon. We have compared the sensitivity ( $y$ intercept) and amplification efficiency (slope) of a standard amplicon prepared from T7-transcribed RNA and a sense oligodeoxynucleotide and found them to be virtually identical. In contrast, the sensitivity of a doublestranded DNA amplicon standard is increased, although the amplification efficiency is unchanged (Overbergh et al. 1999). The advantage of using a single-stranded sense oligodeoxynucleotide is that it significantly simplifies the process of obtaining a standard curve for amplicons up to $100 \mathrm{bp}$, which encompasses most real-time RT-PCR amplicons.

We have constructed standard curves for many target amplicons and have detected differences in both their amplification efficiencies and their sensitivities. This is illustrated by the standard curves for eIF4E (74 bp), GAPDH (226 bp) and Cox-2 (69 bp) shown in Fig. 6. The sensitivity of the eIF4E RT-PCR ( $y$ intercept 39.88) is significantly greater than that of the other two, whereas its amplification efficiency (slope $-2 \cdot 8666$ ) is similar to that of GAPDH $(-3 \cdot 0635)$ and better than that of Cox-2 (-3.893). In our hands, the most sensitive primer/probe combination, detecting the $86 \mathrm{bp}$ guanylyl cyclase $\mathrm{C}$ amplicon, can reliably detect as few as 13 copies of mRNA (Bustin et al. 1999). Conversely, the least sensitive combination could detect only $1 \times 10^{4}$ or more copies of BRF-1 mRNA, an amplicon of $76 \mathrm{bp}$ (Bustin \& McKay 1999). In most cases, the lower detection limit is around 50-500 copies of target mRNA.

\section{Reproducibility}

The RT-PCR reaction is fraught with hazards (Freeman et al. 1999) and is characterised by significant variation and non-reproducibility, even with identical samples between different laboratories (Keilholz et al. 1998). Its reproducibility is inevitably compromised by the variable efficiency of the RT itself and the need for two sequential enzymatic steps (Bishop et al. 1997). The exponential nature of PCR amplification, together with the small quantities of target molecules, means that trivial variations in reaction components and 


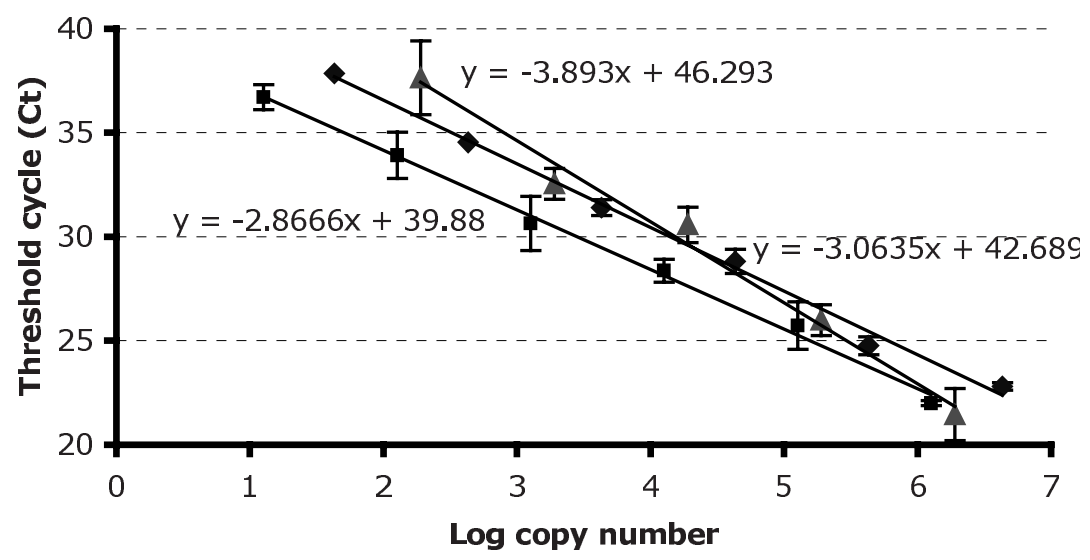

Figure 6. Standard curves for GAPDH $(\bullet), \operatorname{eIF} 4 E(\boldsymbol{\square})$ and Cox-2 ( $\boldsymbol{\Delta})$ amplicons in 'one-enzyme/one-tube' reactions. The plot of the log of initial target copy number versus $C_{t}$ is a straight line. Amplicons lengths are $226 \mathrm{bp}, 74 \mathrm{bp}$ and $69 \mathrm{bp}$ respectively. A 5 -min reverse transcription step at $60{ }^{\circ} \mathrm{C}$ was followed by 40 cycles of a 20 -s denaturation step at $92{ }^{\circ} \mathrm{C}$ and a 30 -s annealing/polymerisation step at $62^{\circ} \mathrm{C}$. Tth polymerase can add approximately $40-50$ bases per second at $62{ }^{\circ} \mathrm{C}$. The error bars indicate the $95 \%$ confidence intervals. The smaller the $\mathrm{C}_{\mathrm{t}}$ value $(y$ intercept) in the regression equation, the greater the sensitivity of the RT-PCR reaction.

thermal cycling conditions and mispriming events during the early stages of the PCR can greatly influence the final yield of the amplified product (Wu et al. 1991). This has created considerable uncertainty about the usefulness and reliability of the RT-PCR assay (Sokoloff et al. 1996), especially when used as a routine clinical diagnostic assay (Gala et al. 1998, de la Taille et al. 1999). It is a particular problem when cancer patients are screened for the presence of micrometastatic disease (Dingemans et al. 1997, Zippelius et al. 1997, Henke \& Loening 1998) and severely limits its usefulness for prognosis and patient surveillance (Lambrechts et al. 1998). Clearly, there is an urgent requirement for stringent quality control (Keilholz 1998), standardisation of the sample acquisition (Jung et al. 1997) and processing processes (Schittek et al. 1999), the RT-PCR procedure (Raj et al. 1998) and the detection of the RT-PCR products (Hughes \& Goldman 1990).

Optimisation and consistency are as critical for obtaining reproducible results using real-time RTPCR as they are for conventional methods. However, there can be no doubt that real-time RT-PCR assays are significantly less variable than any conventional RT-PCR procedure. Where measured, the coefficient of variation for $\mathrm{C}_{t}$ data has been shown to be very low, at less than 2\% for the Taqman (Heid et al. 1996, Gerard et al. 1998) and as little as $0.4 \%$ for the Lightcycler (Wittwer et al. 199ba), which is significantly better than the $14 \%$ reported for conventional

www.endocrinology.org
RT-PCR (Zhang et al. 1997). In our experience using Taqman, the variability between duplicates and triplicates within the same run, and between different runs, is usually between 0 and $5 \%$.

Reproducibility is influenced by parameters such as distribution statistics (Poisson's law) (de Vries et al. 1999), and $C_{t}$ data are less reproducible when working with very low copy numbers, because of the stochastic effects in the quantification of small numbers of target molecules (Peccoud \& Jacob 1996). Particle distribution statistics predict that it will require a much greater number of replicates to differentiate five from 10 copies of RNA than for the differentiation of 5000 from 10000 copies. Of course, this emphasises the importance of repetitive testing in clinical samples. We have seen some evidence that $C_{t}$ values obtained from short amplicons show greater reproducibility than those obtained from long ones. It is also likely that amplification efficiency influences reproducibility. Regardless, one of the strengths of these assays is the ease with which it is possible to determine multiple $C_{t}$ values for every sample, which encourages replicate determinations of the same sample and permits the application of statistical analyses to the quantification procedure.

\section{Normalisation}

RT-PCR-specific errors in the quantification of mRNA transcripts are easily compounded by any 
variation in the amount of starting material between samples. This is especially relevant when the samples have been obtained from different individuals, and will result in the misinterpretation of the expression profiles of the target genes. Consequently, the question of what constitutes an appropriate standard arises (Thellin et al. 1999), and constitutes an important aspect of experimental design.

The accepted method for minimising these errors and correcting for sample-to-sample variation is to amplify, simultaneously with the target, a cellular RNA that serves as an internal reference against which other RNA values can be normalised (Karge et al. 1998). The ideal internal standard should be expressed at a constant level among different tissues of an organism, at all stages of development, and should be unaffected by the experimental treatment. In addition, an endogenous control should also be expressed at roughly the same level as the RNA under study. In the absence of any one single RNA with a constant level of expression in all these situations (Haberhausen et al. 1998, Thellin et al. 1999), three RNAs are most commonly used to normalise patterns of gene expression. The mRNAs specifying the housekeeping genes glyceraldehyde3 -phosphate-dehydrogenase (GAPDH) and $\beta$-actin and are ribosomal RNAs (rRNA), although other mRNAs have been used occasionally - for example histone H3 (Kelley et al. 1993) and cyclophilin (Haendler et al. 1987).

\section{B-Actin}

$\beta$-Actin mRNA is expressed at moderately abundant levels in most cell types and encodes a ubiquitous cytoskeleton protein. It was one of the first RNAs to be used as an internal standard, and it is still advocated as a quantitative reference for RT-PCR assays (Kreuzer et al. 1999). This is despite widespread evidence that its levels of transcription can vary widely in response to experimental manipulation in human breast epithelial cells (Spanakis 1993), and blastomeres (Krussel et al. 1998), as well as in various porcine tissues (Foss et al. 1998) and canine myocardium (Carlyle et al. 1996). In addition, the presence of pseudogenes interferes with the interpretation of results (Dirnhofer et al. 1995, Raff et al. 1997, Mutimer et al. 1998) and primers commonly used for detecting $\beta$-actin mRNA amplify DNA also (Dakhama et al. 1996).

\section{GAPDH}

The RNA encoding GAPDH is a ubiquitously expressed, moderately abundant message. It is frequently used as an endogenous control for quantitative RT-PCR analysis because, in some experimental systems, its expression is constant at different times and after experimental manipulation (Edwards \& Denhardt 1985, Winer et al. 1999). However, there is overwhelming evidence suggesting that its use as an internal standard is inappropriate (Oliveira et al. 1999, Thellin et al. 1999). GAPDH concentrations vary significantly between different individuals (Bustin et al. 1999), during pregnancy (Cale et al. 1997), with developmental stage (Puissant et al. 1994, Calvo et al. 1997), during the cell cycle (Mansur et al. 1993) and after the addition of the tumour promoter 12-Otetradecanoyl-phorbol-13-acetate (Spanakis 1993), dexamethasone (Oikarinen et al. 1991) and carbon tetrachloride (Goldsworthy et al. 1993). Insulin stimulates GAPDH transcription (Rolland et al. 1995, Barroso et al. 1999) through multiple insulinresponsive elements in its promoter (Alexander et al. 1988, Nasrin et al. 1990), at least one of which is recognised by C/EBP (Alexander-Bridges et al. 1992). Similarly, the calcium ionophore A23187 induces GAPDH transcription through specific motifs in its promoter (Chao et al. 1990). Growth hormone (Freyschuss et al. 1994), vitamin D (Desprez et al. 1992), oxidative stress (Ito et al. 1996), hypoxia (Graven et al. 1994, Zhong \& Simons 1999), manganese (Hazell et al. 1999) and the tumour suppressor TP53 (Chen et al. 1999), have all been shown to activate its transcription, which is also inducible in endothelial cells (Rimarachin et al. 1992) and during apoptosis (Ishitani et al. 1997). Furthermore, it has been shown to be upregulated in cancer - for example in rat hepatomas (Chang et al. 1998), malignant murine cell lines (Bhatia et al. 1994) and human prostate carcinoma (Ripple \& Wilding 1995). Conversely, food deprivation (Yamada et al. 1997) and retinoic acid (Barroso et al. 1999) downregulate GAPDH transcription in the gut and in adipocytes, respectively. Finally, numerous transcription regulatory domains have been identified in the yeast GAPDH promoter, again suggesting that this gene is subject to complex transcriptional regulation (Yagi et al. 1994).

We have previously used real-time RT-PCR to demonstrate that there is wide variation in the levels of transcription of GAPDH mRNA in nucleated blood cells, between individuals and between samples taken from the same individual at different time points (Bustin et al. 1999). An analysis of colon epithelial samples taken from an additional 51 patients corroborates these earlier findings (Fig. 7). Copy numbers ranged from $7.9 \times 10^{4}$ to $9.6 \times 10^{9}$, with a median of $3 \cdot 4 \times 10^{8}$ copies of GAPDH mRNA/ $\mu$ g total RNA. This confirms that the use of 


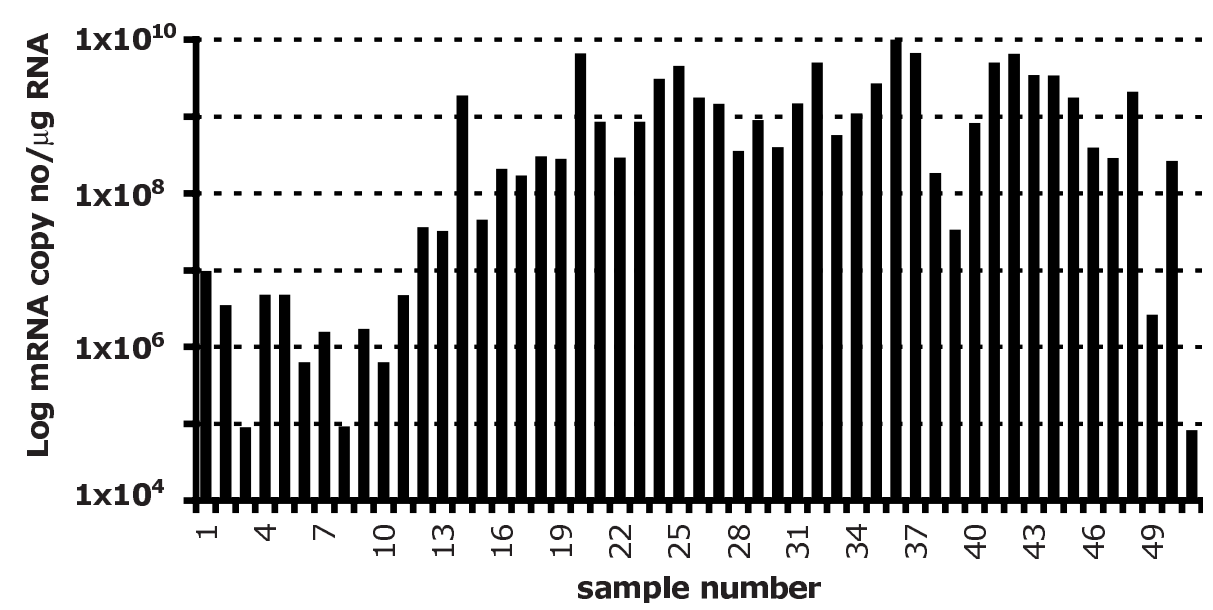

FIGURE 7. GAPDH mRNA levels in normal colon epithelium from 51 individuals. Fifty nanograms total RNA from normal colon epithelium was analysed by quantitative RT-PCR analysis using the primers, probe and one-enzyme/one-tube reaction conditions described above. mRNA copy numbers were calculated from the GAPDH standard curve generated in Fig. 6.

GAPDH to normalise RNA levels in experiments that involve using mRNA from different individuals is inaccurate and should be discouraged. In light of all this evidence, it is a mystery why GAPDH continues to find favour as an internal standard.

\section{rRNA}

rRNAs, which constitute $85-90 \%$ of total cellular RNA, are useful internal controls, as the various rRNA transcripts are generated by a distinct polymerase (Paule \& White 2000) and their levels are less likely to vary under conditions that affect the expression of mRNAs (Barbu \& Dautry 1989). Indeed, they have been shown to be more reliable than either of the housekeeping genes in rat livers (de Leeuw et al. 1989), human skin fibroblasts (Mansur et al. 1993) and human (Zhong \& Simons 1999) and mouse (Bhatia et al. 1994) malignant cell lines. However, rRNA transcription can be affected by biological factors and drugs (Spanakis 1993) and the variation in levels of transcription between samples taken from different individuals has not been quantified. In addition, there are two other drawbacks to its use: rRNA cannot be used for normalisation when quantitating targets that have been enriched for mRNA because it is lost during mRNA purification, and rRNA is expressed at much greater levels than target mRNAs.

\section{Alternatives}

Clearly, this raises questions about how to compare copy numbers between samples obtained from different individuals or from different tissues. For RNA extracted from tissue culture cells or from blood - for example when haematological malignanciesare under investigation - target gene copy numbers can be readily expressed as copy numbers/ cell. This is not possible when the RNA has been extracted from solid tissue or cancers. Therefore, it is necessary to find another means of normalising their copy numbers. Until we identify a more appropriate measure, in our laboratory we relate all copy numbers to total RNA concentration, which we measure accurately using a Genequant II spectrophotometer (Amersham Pharmacia Biotech). Copy numbers of target genes are then recorded as copy number per $\mu$ g total RNA. There are obvious limitations to this approach. Total RNA levels may be increased in highly proliferating cells and this will affect the accuracy of any comparison of absolute copy numbers between normal and tumour cells. As rRNA makes up the bulk of total RNA, the reservations expressed earlier also apply. In addition, the accuracy of the quantification will be critically dependent on the accuracy of RNA measurement. The major disadvantages of the $\mathrm{A}_{260}$ method are the large relative contribution that proteins and free nucleotides make to the signal, the inability to distinguish between DNA and RNA, the interference caused by contaminants commonly found in nucleic acid preparations, and the relative insensitivity of the assay. However, the use of fluorescent nucleic acid stains - for example RiboGreen RNA quantitation (Molecular Probes, Eugene, OR, USA) - alleviates many of these problems and can detect as little as $5 \mathrm{ng} / \mathrm{ml} \mathrm{RNA}$ (Jones et al. 1998). 
In our hands, there is good agreement between levels of transcription of various mRNAs calculated on the basis of total RNA concentration and published data using other techniques, such as immunocytochemical detection of their translation products. Nevertheless, it must be clearly stated that none of the methods used for standardisation between samples is completely satisfactory, and individual experimental conditions will dictate what the most appropriate normaliser should be. Clearly, the ability to achieve absolute quantification of target nucleic acids makes the search for a relevant and universal means of comparing and normalising between samples very urgent.

\section{APPLICATIONS}

\section{Quantification}

Straightforward quantification is easily accomplished by any of the methods described above, and there is probably little to choose between them in terms of their sensitivity, although hybridisationbased assays are more specific than those dependent on DNA-binding dyes and there is some evidence that molecular beacons are a little more specific than linear probes (Tyagi et al. 1998). The Taqman assay has been used to quantitate transcription from individual cells (Fink et al. 1998) and paraffinembedded tissue (Sheils \& Sweeney 1999), to investigate tissue-distribution proteins associated with signal transduction (Bustin \& McKay 1999), for cytokine mRNA profiling from fresh (Overbergh et al. 1999) and stored frozen cells (Kruse et al. 1997) and for quantitating the RNA component of human telomerase (Yajima et al. 1998). Its potential applications in medical diagnostics are wide-ranging and it has been used to screen serum for the diagnosis of genetic diseases (Kaplan et al. 1992), the presence of viral (Morris et al. 1996, Berger et al. 1998, Mercier et al. 1999) and bacterial (Norton \& Batt 1999) pathogens, detection of colorectal (Bustin et al. 1999) and melanoma (de Vries et al. 1999) cells in patients' blood, and quantification of c-myc (Bieche et al. 1999a) or ERBB2 (Bieche et al. 1999b) transcription in breast cancer.

Molecular beacons have been used to detect RNAs from a single cell (Steuerwald et al. 1999) and from within living cells (Matsuo 1998, Sokol et al. 1998) and for other standard research (Lewin et al. 1999) and diagnostic (Arnold et al. 1999) RT-PCR applications.

The range of applications for the Lightcycler are similarly wide, and include detection of minimal residual disease (Eckert et al. 2000), cancer cells in the peritoneal cavity of patients with gastrointestinal and gynaecological malignancies (Nakanishi et al. 1999) and pathogens (Mathews et al. 1999), and monitoring delivery, expression and maintenance of transgenes (Thorpe \& Porteous 1999).

\section{Mutation/allele detection}

The flexibility of the Lightcycler design currently gives it an advantage over the Taqman system for the detection of mutations or allelic variants and it has been used extensively in molecular diagnostics (Aslanidis et al. 1999, Nakao et al. 2000). Two alternative procedures depending on melting-curve analysis have been developed. The first uses a sense primer internally labelled with an acceptor dye together with a donor-labelled probe that is completely complementary to the wild-type sense strand (Lay \& Wittwer 1997, Bernard et al. 1998a). After asymmetric amplification, the probe is annealed to the extension product of the labelled primer. This brings the fluorophores into contact close enough for resonance energy transfer to occur. As the temperature increases, the probe melts from its target, decreasing the resonance energy transfer. If there is no mismatch, melting occurs at a characteristic temperature that is greater than if a single base mutation is present (Bernard et al. 1998b, Cane et al. 1999, Aoshima et al. 2000).

The second procedure is similar, but uses two hybridisation probes (Bernard et al. 1999, Bollhalder et al. 1999). One, the sensor, covers the site of the mutation, and the other one, the anchor, is designed to be longer, with a greater $T_{\mathrm{m}}$ and generates the fluorescent signal. The probe hybridisation status is monitored continuously as the temperature is slowly increased and characteristic, sequence-specific probe melting curves are generated. A single base mismatch under the probe decreases the $T_{\mathrm{m}}$ by as little as $3{ }^{\circ} \mathrm{C}$ for $\mathrm{G}-\mathrm{T}$ and as much as $10{ }^{\circ} \mathrm{C}$ for $\mathrm{A}-\mathrm{C}$ mismatches. The recent introduction of peptide nucleic acids (PNA) (Corey 1997) offers additional scope for this technology. These DNA mimics can bind DNA independently of salt concentration and demonstrate significantly greater specificity in binding to complementary DNA, with the effect that a PNA-DNA mismatch is more destabilising than a DNA-DNA mismatch.

The Taqman system has also be used for allelic discrimination by using probes labelled with different fluorescence reporter dyes (Lee et al. 1993, Livak 1999). The assay is performed under competitive conditions with both probes present in the same tube. Under the correct conditions, there is preferential binding of the exact-match probe, which blocks hybridisation of the mismatched 
probe. In addition, the mismatch itself has a disruptive effect on hybridisation and speeds up the complete dissociation from the template. Both effects result in inefficient cleavage of the mismatch probe. Consequently, an increase in either fluorescent signal indicates homozygosity, whereas an increase in both signals indicates heterozygosity. A recent improvement involves the use of probes containing 5-propyne- $2^{\prime}$-deoxyuridine in place of thymidine, which increases the $T_{\mathrm{m}}$ relative to standard Taqman probes and is useful when amplifying sequences with high $\mathrm{A} / \mathrm{T}$ content. Nevertheless, the need to carry out the PCR reaction between $60{ }^{\circ} \mathrm{C}$ and $62{ }^{\circ} \mathrm{C}$ makes it more difficult to achieve perfect discrimination between mismatch and exact-match probes. This is of particular relevance when attempting mutant allelespecific-type amplifications from samples in which only a minority of the templates will contain the targeted mutation - for example detecting mutant $\mathrm{K}$-ras in the blood of patients with colorectal cancer.

\section{Multiplex RT-PCR}

Detailed diagnostic and scientific analyses are often restricted by the limited availability of biological material. Multiplex RT-PCR is a time- and reagent-saving amplification technique in which multiple primer sets are used to amplify multiple specific targets simultaneously (Edwards \& Gibbs 1994) from the same sample. In principle, all real-time detection systems are capable of simultaneous detection of multiple fluorescent dyes. However, successful multiplexing is never trivial, and requires careful consideration about the suitability of both chemistry and instrumentation. One limitation arises from the limited availability of multiple fluorescent reporters with good spectral resolution. Both the hydrolysis and hybridisation probe methodologies require the interaction of two different fluorescent dyes per target, and each probe or probe set requires a different pair of fluorophores. Consequently, fewer probes can be distinguished from each other in a multiplex assay. Molecular beacons, in contrast, use a universal, non-fluorescent quencher and require only a single fluorophore per probe. Therefore, use of molecular beacons has the potential to be used to identify more targets per reaction. A second limitation is that the use of fluorophores is dependent on the excitation and detection characteristics of the individual spectrofluorimetric thermal cyclers. The ABI 7700 uses a laser with a fixed excitation wavelength, which limits the fluorophores to those that can be efficiently excited by its blue laser, preventing the use of fluorophores that fluoresce in the far-red wavelengths. In addition, it can detect fluorescence only between $500 \mathrm{~nm}$ and $660 \mathrm{~nm}$. The threechannel fluorimeter design of the Lightcycler restricts it to detecting a maximum of three fluorescent dyes simultaneously, whereas the Biorad instrument has the potential to excite and detect emission from the widest range of fluorophores; however, the latter has been launched only recently.

There are relatively few reports of multiplexing using any of these systems. The Taqman system has been used successfully to quantitate up to three (Sharma et al. 1999, Shin et al. 1999) targets, with no apparent reduction in sensitivity compared with the individual reactions (Moody et al. 2000). We have tried to use the Taqman procedures for K-ras codon 12 mutant-specific multiplexing, but have had inconsistent results. The non-fluorescent quencher used by molecular beacons allows the quantification of four pathogenic retroviruses simultaneously in blood (Vet et al. 1999) and the Lightcycler has been used to detect two independent targets simultaneously (Bernard et al. 1999, Lee et al. 1999a, von Ahsen et al. 2000).

The potential for combining several dyes with instrumentation that allows synchronous scanning of excitation and emission wavelengths has been demonstrated with the detection of six PCR products in one reaction (Lee et al. 1999b). In addition, the recent introduction of the Biorad instrument with a variable-wavelength light source and a high-resolution detector should allow the use of a wider range of fluorophores and the accommodation of more probes in the same assay.

The final difficulty is associated with limitations caused by mutual interference of multiple sets of PCR primers, which can reduce the dynamic range of the sensitivity and make quantification unreliable. Furthermore, the efficiency of multiplex detection is significantly affected by the extension time and the concentrations of dNTPs, primers and $\mathrm{MgCl}_{2}$ (Seoh et al. 1998, James 1999). Vastly different levels of target mRNAs will cause quantification problems even for real-time detection, as the exponential phase of amplification of the less abundant mRNA will not overlap with that of the highly abundant target. Therefore, in practice, if accurate quantification is the main aim, it is probably best to limit multiplexing to the detection of two or three transcripts.

\section{Detection of mRNA splice variants}

Alternative splicing of RNAs is an important component of cell-specific gene regulation that contributes to the fine-tuning of gene expression 
and the functional diversification of proteins (Lopez 1998). It permits an additional tissue-specific level of regulation, as the mRNA can be transcribed from the same promoter, but in each tissue the RNA transcript can be spliced in a particular way to produce a different mRNA and hence protein. Alternative RNA splicing is widespread, with the Alternative Splicing Database (ASD) currently listing 1922 protein and 2486 DNA sequences (Dralyuk et al. 2000). The combined amplification/ hybridisation approach of real-time RT-PCR assays is ideally suited for the detection and quantification of known splice variants. For example, hormonal regulation of gene expression can occur through the direct regulation of mRNA splicing (Chew 1997). The role of these alternatively spliced products in normal physiology has been difficult to determine, partly because detection of alternative transcripts using conventional procedures is time-consuming (Winkler et al. 1999) and their quantification, although reasonably accurate, requires extensive additional processing (Robinson et al. 1997), as discussed previously. The specificity of the realtime RT-PCR assay allows the detection of multiple mRNA splice variants, as they can be distinguished reliably by a combination of exon-specific primers and an appropriate probe (Kafert et al. 1999) (Fig. 8). Probes designed to hybridise to specific exon splice junctions will detect and allow quantification of individual splice variants (Fig. 8A,C,D). Alternatively, probes designed to hybridise wholly within an exon will result in the more general identification of all mRNAs defined by the exon-specific upstream and downstream primer sequences (Fig. 8B). Therefore, judicious arrangement of primer/probe combinations allows maximum information about the presence, and the levels of, any number of mRNA splice variants to be gathered with a minimum of complexity and trouble. Importantly, because the results obtained are ratios of one splice variant to another, the problems of normalisation become irrelevant.

\section{Cost considerations}

In technical terms, there is very little difference between the hybridisation-dependent real-time RT-PCR systems and they easily outperform conventional RT-PCR assays. Their main problem is the requirement for dedicated, sophisticated spectrofluorimetric thermal cyclers, which are expensive to purchase and maintain. The ABI 7700 Prism is significantly more expensive to purchase than either the Lightcycler or Biorad's instrument, and all three are more likely to be part of a core facility than on the bench in every laboratory.

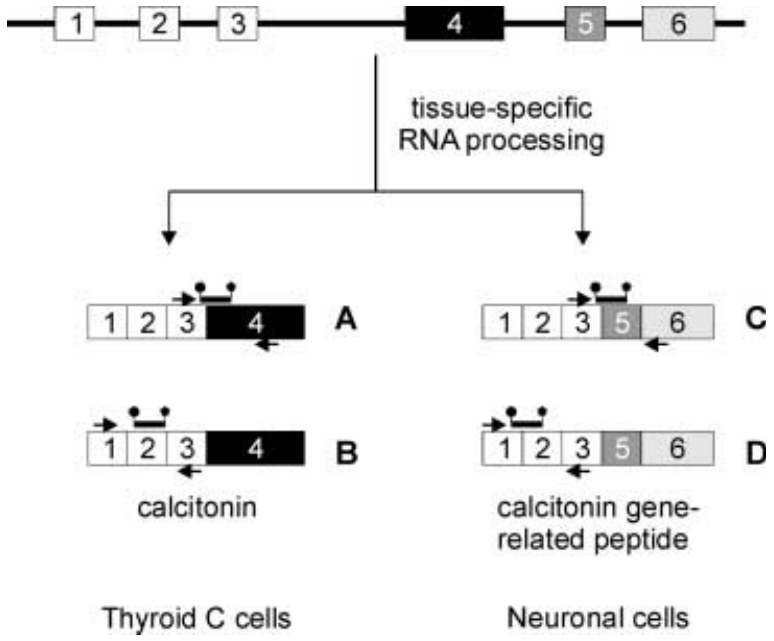

FIGURE 8. Detection of splice variants of the calcitonin/ calcitonin gene-related peptide gene. This gene undergoes alternative $\mathrm{mRNA}$ processing in thyroid $\mathrm{C}$ cells and in neuronal cells to generate two mRNA molecules specifying two distinct peptide hormones. $(\mathrm{A}, \mathrm{C})$ The two splice variants can be distinguished easily through the use of splice-junction-specific probes. This permits simple comparison between the relative levels of transcription of the two splice variants. (B,D) The levels of either mRNAs, or any other possible variants, can be quantified by designing a primer/probe set that amplifies the common $5^{\prime}$ end of the mRNA. Again, the probe can be designed to hybridise either to a splice junction or to one exon only.

However, as the opportunities for using quantitative RT-PCR in a wide variety of settings continue to expand, it is likely that more cost-effective solutions will be developed that will make this assay more easily accessible.

DNA dye-binding assays are the cheapest option for performing kinetic RT-PCR assays, as they do not require an amplicon-specific probe. Hybridisation analyses require a separate primer set, together with fluorescent-labelled probe for each amplicon under investigation, which can make gene expression profiling experiments costly. In addition, assays carried out on the ABI 7700 have an absolute requirement for a reference dye in the reaction mixture. That reaction buffer can be obtained only as part of a complete kit, resulting in additional expense. In combination, all this adds significantly to the costs of performing quantitative real-time RT-PCR assays. However, kinetic RT-PCR primers and probes are designed according to very strict criteria, with narrowly defined divalent cation and $T_{\mathrm{m}}$ ranges. Together with the reliability and ease of these assays, this reduces the need to waste reagents for assay optimisation. Furthermore, their 
specificity obviates the need to sequence or use Southern blotting to confirm the identity of the amplicons, and produces significant saving on researchers' time. We have designed and used Taqman primer/probe sets for more than 100 mRNA targets, and have achieved acceptable amplification every time, without any need for optimisation. The ability to obtain immediate results also compensates for the increased consumables cost incurred, as does the ease with which numerous templates can be quantitated in a very short period.

\section{CONCLUSIONS}

Kinetic, or real-time, fluorescence RT-PCR significantly simplifies and accelerates the process of producing reproducible quantification of mRNAs. With the use of appropriate standard curves, absolute copy numbers of mRNA can easily be calculated. Several chemistries are available and their combination of amplification with simultaneous hybridisation means that the high sensitivity of the assay is not compromised by concerns about its specificity. In addition, kinetic RT-PCR assays are readily standardised, making the comparison of results from different laboratories easier and more reliable. Therefore, real-time RT-PCR must be the method of choice for any experiments requiring sensitive, specific and reproducible quantification of mRNA.

\section{ACKNOWLEDGEMENTS}

I would like to thank Julia White and Paul Jenkins for reading this manuscript. The work described in this review was funded by grants from the Royal Society and the London Immunotherapy Cancer Trust.

\section{REFERENCES}

Adams MW \& Kelly RM 1994 Thermostability and thermoactivity of enzymes from hyperthermophilic Archaea. Bioorganic and Medicinal Chemistry 2 659-667.

von Ahsen N, Oellerich M \& Schutz E 2000 Use of two reporter dyes without interference in a single-tube rapidcycle PCR: alpha(1)-antitrypsin genotyping by multiplex real-time fluorescence PCR with the LightCycler. Clinical Chemistry 46 156-161.

Alexander MC, Lomanto M, Nasrin N \& Ramaika C 1988 Insulin stimulates glyceraldehyde-3-phosphate dehydrogenase gene expression through cis-acting DNA sequences. PNAS 85 5092-5096.
Alexander-Bridges M, Dugast I, Ercolani L, Kong XF, Giere L \& Nasrin N 1992 Multiple insulin-responsive elements regulate transcription of the GAPDH gene. Advances in Enzyme Regulation 32 149-159.

Aoshima T, Sekido Y, Miyazaki T, Kajita M, Mimura S, Watanabe K, Shimokata K \& Niwa T 2000 Rapid detection of deletion mutations in inherited metabolic diseases by melting curve analysis with LightCycler. Clinical Chemistry 46 119-122.

Arnold SF, Tims E \& Mcgrath BE 1999 Identification of bone morphogenetic proteins and their receptors in human breast cancer cell lines: importance of bmp2. Cytokine $\mathbf{1 1}$ 1031-1037.

Aslanidis C, Nauck M \& Schmitz G 1999 High-speed prothrombin G A 20210 and methylenetetrahydrofolate reductase $\mathrm{C}$ T 677 mutation detection using real-time fluorescence PCR and melting curves. Biotechniques 27 234-238.

Barbu V \& Dautry F 1989 Northern blot normalization with a 28S rRNA oligonucleotide probe. Nucleic Acids Research 17 7115 .

Barroso I, Benito B, Garci-Jimenez C, Hernandez A, Obregon MJ \& Santisteban P 1999 Norepinephrine, tri-iodothyronine and insulin upregulate glyceraldehyde-3-phosphate dehydrogenase mRNA during Brown adipocyte differentiation. European Fournal of Endocrinology 141 169-179.

Bauer P, Rolfs A, Regitz-Zagrosek V, Hildebrandt A \& Fleck E 1997 Use of manganese in RT-PCR eliminates PCR artifacts resulting from DNase I digestion. Biotechniques 22 1128-1132.

Becker-Andre M 1993 Absolute levels of mRNA by polymerase chain reaction-aided transcript titration assay. Methods in Enzymology 218 420-445.

Beckman RA, Mildvan AS \& Loeb LA 1985 On the fidelity of DNA replication: manganese mutagenesis in vitro. Biochemistry 24 5810-5817.

Berger A, Braner J, Doerr HW \& Weber B 1998 Quantification of viral load: clinical relevance for human immunodeficiency virus, hepatitis $\mathrm{B}$ virus and hepatitis $\mathrm{C}$ virus infection. Intervirology $4124-34$.

Bernard PS, Ajioka RS, Kushner JP \& Wittwer CT $1998 a$ Homogeneous multiplex genotyping of hemochromatosis mutations with fluorescent hybridization probes. American Fournal of Pathology 153 1055-1061.

Bernard PS, Lay MJ \& Wittwer CT $1998 b$ Integrated amplification and detection of the C677T point mutation in the methylenetetrahydrofolate reductase gene by fluorescence resonance energy transfer and probe melting curves. Analytical Biochemistry 255 101-107.

Bernard PS, Pritham GH \& Wittwer CT 1999 Color multiplexing hybridization probes using the apolipoprotein $\mathrm{E}$ locus as a model system for genotyping. Analytical Biochemistry 273 221-228.

Bhatia P, Taylor WR, Greenberg AH \& Wright JA 1994 Comparison of glyceraldehyde-3-phosphate dehydrogenase and 28S-ribosomal RNA gene expression as RNA loading controls for northern blot analysis of cell lines of varying malignant potential. Analytical Biochemistry 216 223-226.

Bieche I, Laurendeau I, Tozlu S, Olivi M, Vidaud D, Lidereau R \& Vidaud M 1999a Quantitation of MYC gene expression in sporadic breast tumors with a real-time reverse transcription-PCR assay. Cancer Research 59 2759-2765.

Bieche I, Onody P, Laurendeau I, Olivi M, Vidaud D, Lidereau R \& Vidaud M $1999 b$ Real-time reverse transcription-PCR assay for future management of ERBB2-based clinical applications. Clinical Chemistry 45 $1148-1156$. 
Bishop GA, Rokahr KL, Lowes M, McGuinness PH, Napoli J, DeCruz DJ, Wong WY \& McCaughan GW 1997 Quantitative reverse transcriptase-PCR amplification of cytokine mRNA in liver biopsy specimens using a non-competitive method. Immunology and Cell Biology 75 142-147.

Bollhalder M, Mura C, Landt O \& Maly FE 1999 LightCycler $\mathrm{PCR}$ assay for simultaneous detection of the H63D and $\mathrm{S} 65 \mathrm{C}$ mutations in the HFE hemochromatosis gene based on opposite melting temperature shifts. Clinical Chemistry $\mathbf{4 5}$ $2275-2278$.

Bonnet G, Tyagi S, Libchaber A \& Kramer FR 1999 Thermodynamic basis of the enhanced specificity of structured DNA probes. PNAS 96 6171-6176.

Borson ND, Salo WL \& Drewes LR 1992 A lock-docking oligo(dT) primer for $5^{\prime}$ and $3^{\prime}$ RACE PCR. PCR Methods and Applications 2 144-148.

Borson ND, Strausbauch MA, Wettstein PJ, Oda RP, Johnston SL \& Landers JP 1998 Direct quantitation of RNA transcripts by competitive single-tube RT-PCR and capillary electrophoresis. Biotechniques 25 130-137.

Brooks EM, Sheflin LG \& Spaulding SW 1995 Secondary structure in the $3^{\prime}$ UTR of EGF and the choice of reverse transcriptases affect the detection of message diversity by RT-PCR. Biotechniques 19 806-815.

Bucher P 1999 Regulatory elements and expression profiles. Current Opinion in Structural Biology 9 400-407.

Buell GN, Wickens MP, Payvar F \& Schimke RT 1978 Synthesis of full length cDNAs from four partially purified oviduct mRNAs. Fournal of Biological Chemistry 253 $2471-2482$.

Bustin SA \& Dorudi S 1998 Molecular assessment of tumour stage and disease recurrence using PCR-based assays. Molecular Medicine Today 4 389-396.

Bustin SA \& McKay IA 1999 The product of the primary response gene BRF1 inhibits the interaction between 14-3-3 proteins and cRaf-1 in the yeast trihybrid system. DNA and Cell Biology 18 653-661.

Bustin SA, Gyselman VG, Williams NS \& Dorudi S 1999 Detection of cytokeratins $19 / 20$ and guanylyl cyclase C in peripheral blood of colorectal cancer patients. British Fournal of Cancer 79 1813-1820.

Cale JM, Millican DS, Itoh H, Magness RR \& Bird IM 1997 Pregnancy induces an increase in the expression of glyceraldehyde-3-phosphate dehydrogenase in uterine artery endothelial cells. Fournal of the Society for Gynecologic Investigation 4 284-292.

Calvo EL, Boucher C, Coulombe Z \& Morisset J 1997 Pancreatic GAPDH gene expression during ontogeny and acute pancreatitis induced by caerulein. Biochemical and Biophysical Research Communications 235 636-640.

Cane PA, Cook P, Ratcliffe D, Mutimer D \& Pillay D 1999 Use of real-time PCR and fluorimetry to detect lamivudine resistance-associated mutations in hepatitis B virus. Antimicrobial Agents and Chemotherapy 43 1600-1608.

Carlyle WC, Toher CA, Vandervelde JR, McDonald KM, Homans DC \& Cohn JN 1996 Changes in beta-actin mRNA expression in remodeling canine myocardium. Fournal of Molecular and Cellular Cardiology 28 53-63.

Chang TJ, Juan CC, Yin PH, Chi CW \& Tsay HJ 1998 Up-regulation of beta-actin, cyclophilin and GAPDH in N1S1 rat hepatoma. Oncology Reports 5 469-471.

Chao CC, Yam WC \& Lin-Chao S 1990 Coordinated induction of two unrelated glucose-regulated protein genes by a calcium ionophore: human BiP/GRP78 and GAPDH Biochemical and Biophysical Research Communications 171 431-438.
Chelly J, Concordet JP, Kaplan JC \& Kahn A 1989 Illegitimate transcription: transcription of any gene in any cell type. PNAS 86 2617-2621.

Chen RW, Saunders PA, Wei H, Li Z, Seth P \& Chuang DM 1999 Involvement of glyceraldehyde-3-phosphate dehydrogenase (GAPDH) and p53 in neuronal apoptosis: evidence that GAPDH is upregulated by p53. Fournal of Neuroscience 19 9654-9662.

Chew SL 1997 Alternative splicing of mRNA as a mode of endocrine regulation. Trends in Endocrinology and Metabolism 8 405-413.

Chiocchia G \& Smith KA 1997 Highly sensitive method to detect mRNAs in individual cells by direct RT-PCR using Tth DNA polymerase. Biotechniques 22 312-318.

Cline J, Braman JC \& Hogrefe HH 1996 PCR fidelity of pfu DNA polymerase and other thermostable DNA polymerases. Nucleic Acids Research 24 3546-3551.

Corey DR 1997 Peptide nucleic acids: expanding the scope of nucleic acid recognition. Trends in Biotechnology 15 224-229.

Corey E, Arfman EW, Liu AY \& Vessella RL 1997 Improved reverse transcriptase-polymerase chain reaction protocol with exogenous internal competitive control for prostate-specific antigen mRNA in blood and bone marrow. Clinical Chemistry 43 443-452.

Cusi MG, Valassina M \& Valensin PE 1994 Comparison of M-MLV reverse transcriptase and Tth polymerase activity in RT-PCR of samples with low virus burden. Biotechniques 17 1034-1036.

Dakhama A, Macek V, Hogg JC \& Hegele RG 1996 Amplification of human beta-actin gene by the reverse transcriptase-polymerase chain reaction: implications for assessment of RNA from formalin-fixed, paraffin-embedded material. Fournal of Histochemistry and Cytochemistry $\mathbf{4 4}$ $1205-1207$.

Desjardin LE, Perkins MD, Wolski K, Haun S, Teixeira L, Chen Y, Johnson JL, Ellner JJ, Dietze R, Bates J, Cave MD \& Eisenach KD 1999 Measurement of sputum Mycobacterium tuberculosis messenger RNA as a surrogate for response to chemotherapy. American Fournal of Respiratory and Critical Care Medicine $\mathbf{1 6 0}$ 203-210.

Desprez PY, Poujol D \& Saez S 1992 Glyceraldehyde-3phosphate dehydrogenase (GAPDH, E.C. $1 \cdot 2 \cdot 1 \cdot 12$.) gene expression in two malignant human mammary epithelial cell lines: BT-20 and MCF-7. Regulation of gene expression by 1,25-dihydroxyvitamin D3 $(1,25-(\mathrm{OH}) 2 \mathrm{D} 3)$. Cancer Letters 64 219-224.

DeStefano JJ, Buiser RG, Mallaber LM, Myers TW, Bambara RA \& Fay PJ 1991 Polymerization and RNase H activities of the reverse transcriptases from avian myeloblastosis, human immunodeficiency, and Moloney murine leukemia viruses are functionally uncoupled. Fournal of Biological Chemistry 266 7423-7431.

Dingemans AM, Brakenhoff RH, Postmus PE \& Giaccone G 1997 Detection of cytokeratin-19 transcripts by reverse transcriptase-polymerase chain reaction in lung cancer cell lines and blood of lung cancer patients. Laboratory Investigation 77 213-220.

Dirnhofer S, Berger C, Untergasser G, Geley S \& Berger P 1995 Human beta-actin retropseudogenes interfere with RT-PCR. Trends in Genetics 11 380-381.

Dralyuk I, Brudno M, Gelfand MS, Zorn M \& Dubchak I 2000 ASDB: database of alternatively spliced genes. Nucleic Acids Research 28 296-297.

Eckert KA \& Kunkel TA 1991 DNA polymerase fidelity and the polymerase chain reaction. PCR Methods and Applications 1 17-24. 
Eckert C, Landt O, Taube T, Seeger K, Beyermann B, Proba J \& Henze G 2000 Potential of LightCycler technology for quantification of minimal residual disease in childhood acute lymphoblastic leukemia. Leukemia 14 316-323.

Edwards DR \& Denhardt DT 1985 A study of mitochondrial and nuclear transcription with cloned cDNA probes. Changes in the relative abundance of mitochondrial transcripts after stimulation of quiescent mouse fibroblasts. Experimental Cell Research 157 127-143.

Edwards MC \& Gibbs RA 1994 Multiplex PCR: advantages, development, and applications. PCR Methods and Applications 3 S65-S75.

Fairman J, Roche L, Pieslak I, Lay M, Corson S, Fox E, Luong C, Koe G, Lemos B, Grove R, Fradkin L \& Vernachio J 1999 Quantitative RT-PCR to evaluate in vivo expression of multiple transgenes using a common intron. Biotechniques 27 566-574.

Fernandez PM, Pluta LJ, Fransson-Steen R, Goldsworthy TL \& Fox TR 1997 Reverse transcription-polymerase chain reaction-based methodology to quantify differential gene expression directly from microdissected regions of frozen tissue sections. Molecular Carcinogenesis 20 317-326.

Ferre F 1992 Quantitative or semi-quantitative PCR: reality versus myth. PCR Methods and Applications 2 1-9.

Fink L, Seeger W, Ermert L, Hanze J, Stahl U, Grimminger F, Kummer W \& Bohle RM 1998 Real-time quantitative RT-PCR after laser-assisted cell picking. Nature Medicine 4 1329-1333.

Foss DL, Baarsch MJ \& Murtaugh MP 1998 Regulation of hypoxanthine phosphoribosyltransferase, glyceraldehyde-3phosphate dehydrogenase and beta-actin mRNA expression in porcine immune cells and tissues. Animal Biotechnology 9 $67-78$.

Freeman WM, Vrana SL \& Vrana KE 1996 Use of elevated reverse transcription reaction temperatures in RT-PCR. Biotechniques 20 782-783.

Freeman WM, Walker SJ \& Vrana KE 1999 Quantitative RT-PCR: pitfalls and potential. Biotechniques 26 112-115.

Freyschuss B, Sahlin L, Masironi B \& Eriksson H 1994 The hormonal regulation of the oestrogen receptor in rat liver: an interplay involving growth hormone, thyroid hormones and glucocorticoids. Fournal of Endocrinology 142 285-298.

Fromant M, Blanquet S \& Plateau P 1995 Direct random mutagenesis of gene-sized DNA fragments using polymerase chain reaction. Analytical Biochemistry 224 347-353.

Funaki NO, Tanaka J, Itami A, Kasamatsu T, Ohshio G, Onodera H, Monden K, Okino T \& Imamura M 1997 Detection of colorectal carcinoma cells in circulating peripheral blood by reverse transcription-polymerase chain reaction targeting cytokeratin-20 mRNA. Life Sciences $\mathbf{6 0}$ $643-652$

Funaki NO, Tanaka J, Ohshio G, Onodera H, Maetani H \& Imamura M 1998 Cytokeratin 20 mRNA in peripheral venous blood of colorectal carcinoma patients. British fournal of Cancer 77 1327-1332.

Gala JL, Heusterspreute M, Loric S, Hanon F, Tombal B, Van Cangh P, De Nayer P \& Philippe M 1998 Expression of prostate-specific antigen and prostate-specific membrane antigen transcripts in blood cells: implications for the detection of hematogenous prostate cells and standardization. Clinical Chemistry 44 472-481.

Gerard GF, Fox DK, Nathan M \& D'Alessio JM 1997 Reverse transcriptase. The use of cloned Moloney murine leukemia virus reverse transcriptase to synthesize DNA from RNA. Molecular Biotechnology 8 61-77.

Gerard CJ, Olsson K, Ramanathan R, Reading C \& Hanania EG 1998 Improved quantitation of minimal residual disease in multiple myeloma using real-time polymerase chain reaction and plasmid-DNA complementarity determining region III standards. Cancer Research 58 3957-3964.

Ghossein RA \& Rosai J 1996 Polymerase chain reaction in the detection of micrometastases and circulating tumor cells. Cancer 78 10-16.

Gibson UE, Heid CA \& Williams PM 1996 A novel method for real time quantitative RT-PCR. Genome Research 6 995-1001.

Giesendorf BA, Vet JA, Tyagi S, Mensink EJ, Trijbels FJ \& Blom HJ 1998 Molecular beacons: a new approach for semiautomated mutation analysis. Clinical Chemistry $\mathbf{4 4}$ 482-486.

Gilliland G, Perrin S, Blanchard K, Bunn HF 1990 Analysis of cytokine mRNA and DNA: detection and quantitation by competitive polymerase chain reaction. PNAS 87 $2725-2729$.

Gilliland G, Perrin S \& Bunn HF 1992 Competitive PCR for quantitation of mRNA. In PCR Protocols: a Guide to Methods and Applications, pp 60-69. Eds MA Innis, DH Gelfand, JJ Sninsky\& TJ White. San Diego, CA: Academic Press.

Goldsworthy SM, Goldsworthy TL, Sprankle CS \& Butterworth BE 1993 Variation in expression of genes used for normalization of Northern blots after induction of cell proliferation. Cell Proliferation 26 511-518.

Grabko VI, Chistyakova LG, Lyapustin VN, Korobko VG \& Miroshnikov AI 1996 Reverse transcription, amplification and sequencing of poliovirus RNA by Taq DNA polymerase. FEBS Letters 387 189-192.

Graven KK, Troxler RF, Kornfeld H, Panchenko MV \& Farber HW 1994 Regulation of endothelial cell glyceraldehyde3 -phosphate dehydrogenase expression by hypoxia. Fournal of Biological Chemistry 269 24446-24453.

Guatelli JC, Whitfield KM, Kwoh DY, Barringer KJ, Richman DD \& Gingeras TR 1990 Isothermal, in vitro amplification of nucleic acids by a multienzyme reaction modeled after retroviral replication. PNAS $\mathbf{8 7} 1874-1878$.

Gut M, Leutenegger CM, Huder JB, Pedersen NC \& Lutz H 1999 One-tube fluorogenic reverse transcription-polymerase chain reaction for the quantitation of feline coronaviruses. Fournal of Virological Methods 77 37-46.

Haberhausen G, Pinsl J, Kuhn CC \& Markert-Hahn C 1998 Comparative study of different standardization concepts in quantitative competitive reverse transcription-PCR assays. Fournal of Clinical Microbiology 36 628-633.

Haendler B, Hofer-Warbinek R \& Hofer E 1987 Complementary DNA for human T-cell cyclophilin. EMBO Fournal 6 947950 .

Hayward AL, Oefner PJ, Sabatini S, Kainer DB, Hinojos CA \& Doris PA 1998 Modeling and analysis of competitive RT-PCR. Nucleic Acids Research 26 2511-2518.

Hazell AS, Desjardins P \& Butterworth RF 1999 Increased expression of glyceraldehyde-3-phosphate dehydrogenase in cultured astrocytes following exposure to manganese. Neurochemistry International 35 11-17.

Heid CA, Stevens J, Livak KJ \& Williams PM 1996 Real time quantitative PCR. Genome Research 6 986-994.

Henke W \& Loening SA 1998 Detection of illegitimate transcripts of prostate-specific antigen mRNA in blood by reverse transcription-polymerase chain reaction. International Fournal of Cancer 77 164-165.

Henke W, Jung M, Jung K, Lein M, Schlechte H, Berndt C, Rudolph B, Schnorr D \& Loening SA 1997 Increased analytical sensitivity of RT-PCR of PSA mRNA decreases diagnostic specificity of detection of prostatic cells in blood. International Fournal of Cancer 70 52-56.

Henley WN, Schuebel KE \& Nielsen DA 1996 Limitations imposed by heteroduplex formation on quantitative RT-PCR. 
Biochemical and Biophysical Research Communications 226 113-117.

Higuchi R, Fockler C, Dollinger G \& Watson R 1993 Kinetic PCR analysis: real-time monitoring of DNA amplification reactions. Biotechnology 11 1026-1030.

Hill WE 1996 The polymerase chain reaction: applications for the detection of foodborne pathogens. Critical Reviews in Food Science and Nutrition 36 23-173.

Hod Y 1992 A simplified ribonuclease protection assay. Biotechniques 13 852-854.

Holodniy M 1994 Clinical application of reverse transcription-polymerase chain reaction for HIV infection. Clinical and Laboratory Medicine 14 335-349.

Hughes T \& Goldman JM 1990 Improved results with PCR for chronic myeloid leukaemia. Lancet 336812.

Ishitani R, Sunaga K, Tanaka M, Aishita H \& Chuang DM 1997 Overexpression of glyceraldehyde-3-phosphate dehydrogenase is involved in low $\mathrm{K}^{+}$-induced apoptosis but not necrosis of cultured cerebellar granule cells. Molecular Pharmacology 51 542-550.

Israeli RS, Miller WH Jr, Su SL, Powell CT, Fair WR, Samadi DS, Huryk RF, DeBlasio A, Edwards ET, Wise GJ, et al. 1994 Sensitive nested reverse transcription polymerase chain reaction detection of circulating prostatic tumor cells: comparison of prostate-specific membrane antigen and prostate-specific antigen-based assays. Cancer Research $\mathbf{5 4}$ 6306-6310.

Ito Y, Pagano PJ, Tornheim K, Brecher P \& Cohen RA 1996 Oxidative stress increases glyceraldehyde-3-phosphate dehydrogenase mRNA levels in isolated rabbit aorta. American Fournal of Physiology $270 \mathrm{H} 81-\mathrm{H} 87$.

James D 1999 A simple and reliable protocol for the detection of apple stem grooving virus by RT-PCR and in a multiplex PCR assay. Fournal of Virological Methods 83 1-9.

Jeffreys AJ, Wilson V, Neumann R \& Keyte J 1988 Amplification of human minisatellites by the polymerase chain reaction: towards DNA fingerprinting of single cells. Nucleic Acids Research 16 10953-10971.

Jones LJ, Yue ST, Cheung CY \& Singer VL 1998 RNA quantitation by fluorescence-based solution assay: RiboGreen reagent characterization. Analytical Biochemistry 265 368-374.

Jung R, Ahmad-Nejad P, Wimmer M, Gerhard M, Wagener C \& Neumaier M 1997 Quality management and influential factors for the detection of single metastatic cancer cells by reverse transcriptase polymerase chain reaction. European Fournal of Clinical Chemistry and Clinical Biochemistry 35 3-10.

Kafert S, Krauter J, Ganser A \& Eder M 1999 Differential quantitation of alternatively spliced messenger RNAs using isoform-specific real-time RT-PCR. Analytical Biochemistry 269 210-213.

Kaplan JC, Kahn A \& Chelly J 1992 Illegitimate transcription: its use in the study of inherited disease. Human Mutation 1 357-360.

Karge WH, Schaefer EJ \& Ordovas JM 1998 Quantification of mRNA by polymerase chain reaction (PCR) using an internal standard and a nonradioactive detection method. Methods in Molecular Biology 110 43-61.

Keilholz U 1998 New prognostic factors in melanoma: mRNA tumour markers. European Fournal of Cancer 34 (Suppl 3) S37-S41.

Keilholz U, Willhauck M, Rimoldi D, Brasseur F, Dummer W, Rass K, de Vries T, Blaheta J, Voit C, Lethe B \& Burchill S 1998 Reliability of reverse transcriptionpolymerase chain reaction (RT-PCR)-based assays for the detection of circulating tumour cells: a quality-assurance initiative of the EORTC Melanoma Cooperative Group. European Fournal of Cancer 34 750-753.
Kelley MR, Jurgens JK, Tentler J, Emanuele NV, Blutt SE \& Emanuele MA 1993 Coupled reverse transcriptionpolymerase chain reaction (RT-PCR) technique is comparative, quantitative, and rapid: uses in alcohol research involving low abundance mRNA species such as hypothalamic LHRH and GRF. Alcohol 10 185-189.

Kotewicz ML, Sampson CM, D’Alessio JM \& Gerard GF 1988 Isolation of cloned Moloney murine leukemia virus reverse transcriptase lacking ribonuclease $\mathrm{H}$ activity. Nucleic Acids Research 16 265-277.

Kreuzer KA, Lass U, Landt O, Nitsche A, Laser J, Ellerbrok H, Pauli G, Huhn D \& Schmidt CA 1999 Highly sensitive and specific fluorescence reverse transcription-PCR assay for the pseudogene-free detection of beta-actin transcripts as quantitative reference. Clinical Chemistry 45 297-300.

Kruse N, Pette M, Toyka K \& Rieckmann P 1997 Quantification of cytokine mRNA expression by RT PCR in samples of previously frozen blood. Fournal of Immunological Methods 210 195-203.

Krussel JS, Huang HY, Simon C, Behr B, Pape AR, Wen Y, Bielfeld P, Polan ML 1998 Single blastomeres within human preimplantation embryos express different amounts of messenger ribonucleic acid for beta-actin and interleukin-1 receptor type I. Fournal of Clinical Endocrinology and Metabolism 83 953-959.

Kwok S \& Higuchi R 1989 Avoiding false positives with PCR. Nature 339 237-238.

Lambrechts AC, 't Veer LJ \& Rodenhuis S 1998 The detection of minimal numbers of contaminating epithelial tumor cells in blood or bone marrow: use, limitations and future of RNA-based methods. Annals of Oncology 9 1269-1276.

Lay MJ \& Wittwer CT 1997 Real-time fluorescence genotyping of factor V Leiden during rapid-cycle PCR. Clinical Chemistry 43 2262-2267.

Lee LG, Connell CR \& Bloch W 1993 Allelic discrimination by nick-translation PCR with fluorogenic probes. Nucleic Acids Research 21 3761-3766.

Lee MA, Brightwell G, Leslie D, Bird H \& Hamilton A 1999a Fluorescent detection techniques for real-time multiplex strand specific detection of Bacillus anthracis using rapid PCR. Fournal of Applied Microbiology 87 218-223.

Lee LG, Livak KJ, Mullah B, Graham RJ, Vinayak RS \& Woudenberg TM $1999 b$ Seven-color, homogeneous detection of six PCR products. Biotechniques 27 342-349.

de Leeuw WJ, Slagboom PE \& Vijg J 1989 Quantitative comparison of mRNA levels in mammalian tissues: $28 \mathrm{~S}$ ribosomal RNA level as an accurate internal control. Nucleic Acids Research 17 10137-10138.

Leone G, van Schijndel H, van Gemen B, Kramer FR \& Schoen CD 1998 Molecular beacon probes combined with amplification by NASBA enable homogeneous, real-time detection of RNA. Nucleic Acids Research 26 2150-2155.

Leutenegger CM, Mislin CN, Sigrist B, Ehrengruber MU, Hofmann-Lehmann R \& Lutz H 1999 Quantitative real-time PCR for the measurement of feline cytokine mRNA. Veterinary Immunology and Immunopathology 71 291-305.

Lewin SR, Vesanen M, Kostrikis L, Hurley A, Duran M, Zhang L, Ho DD \& Markowitz M 1999 Use of real-time PCR and molecular beacons to detect virus replication in human immunodeficiency virus type 1 -infected individuals on prolonged effective antiretroviral therapy. Fournal of Virology 73 6099-6103.

Livak KJ 1999 Allelic discrimination using fluorogenic probes and the 5' nuclease assay. Genetic Analysis 14 143-149.

Livak KJ, Flood SJ, Marmaro J, Giusti W \& Deetz K 1995 Oligonucleotides with fluorescent dyes at opposite ends provide a quenched probe system useful for detecting PCR 
product and nucleic acid hybridization. PCR Methods and Applications 4 357-362.

Lizardi PM, Huang X, Zhu Z, Bray-Ward P, Thomas DC \& Ward DC 1998 Mutation detection and single-molecule counting using isothermal rolling-circle amplification. Nature Genetics 19 225-232.

Lopez AJ 1998 Alternative splicing of pre-mRNA: developmental consequences and mechanisms of regulation. Annual Review of Genetics 32 279-305.

Lyamichev V, Brow MA \& Dahlberg JE 1993 Structurespecific endonucleolytic cleavage of nucleic acids by eubacterial DNA polymerases. Science 260 778-783.

Mansur NR, Meyer-Siegler K, Wurzer JC \& Sirover MA 1993 Cell cycle regulation of the glyceraldehyde-3-phosphate dehydrogenase/uracil DNA glycosylase gene in normal human cells. Nucleic Acids Research 21 993-998.

Marchand J, Bord A, Penarier G, Laure F, Carayon P \& Casellas P 1999 Quantitative method to determine mRNA levels by reverse transcriptase-polymerase chain reaction from leukocyte subsets purified by fluorescence-activated cell sorting: application to peripheral cannabinoid receptors. Cytometry 35 227-234.

Marras SA, Kramer FR \& Tyagi S 1999 Multiplex detection of single-nucleotide variations using molecular beacons. Genetic Analysis 14 151-156.

Martell M, Gomez J, Esteban JI, Sauleda S, Quer J, Cabot B, Esteban R \& Guardia J 1999 High-throughput real-time reverse transcription-PCR quantitation of hepatitis $\mathrm{C}$ virus RNA. Fournal of Clinical Microbiology 37 327-332.

Mathews SA, Volp KM \& Timms P 1999 Development of a quantitative gene expression assay for Chlamydia trachomatis identified temporal expression of sigma factors. FEBS Letters 458 354-358.

Matsuo T 1998 In situ visualization of messenger RNA for basic fibroblast growth factor in living cells. Biochimica et Biophysica Acta 1379 178-184.

Melton DA, Krieg PA, Rebagliati MR, Maniatis T, Zinn K \& Green MR 1984 Efficient in vitro synthesis of biologically active RNA and RNA hybridization probes from plasmids containing a bacteriophage SP6 promoter. Nucleic Acids Research 12 7035-7056.

Mercier B, Burlot L \& Ferec C 1999 Simultaneous screening for HBV DNA and HCV RNA genomes in blood donations using a novel TaqMan PCR assay. Fournal of Virological Methods 77 1-9.

Montgomery RA \& Dallman MJ 1997 Semi-quantitative polymerase chain reaction analysis of cytokine and cytokine receptor gene expression during thymic ontogeny. Cytokine 9 $717-726$.

Moody A, Sellers S \& Bumstead N 2000 Measuring infectious bursal disease virus RNA in blood by multiplex real-time quantitative RT-PCR. Fournal of Virological Methods $\mathbf{8 5}$ $55-64$.

Morris T, Robertson B \& Gallagher M 1996 Rapid reverse transcription-PCR detection of hepatitis $\mathrm{C}$ virus RNA in serum by using the TaqMan fluorogenic detection system. Fournal of Clinical Microbiology 34 2933-2936.

Morrison TB, Weis JJ \& Wittwer CT 1998 Quantification of low-copy transcripts by continuous SYBR Green I monitoring during amplification. Biotechniques 24 954-962.

Mutimer H, Deacon N, Crowe S \& Sonza S 1998 Pitfalls of processed pseudogenes in RT-PCR. Biotechniques 24 585-588.

Myers TW, Gelfand DH 1991 Reverse transcription and DNA amplification by a Thermus thermophilus DNA polymerase. Biochemistry 30 7661-7666.

Nakanishi H, Kodera Y, Yamamura Y, Kuzuya K, Nakanishi T, Ezaki T \& Tatematsu M 1999 Molecular diagnostic detection of free cancer cells in the peritoneal cavity of patients with gastrointestinal and gynecologic malignancies. Cancer Chemotherapy and Pharmacology 43 (Suppl) S32-S36.

Nakao M, Janssen JW, Seriu T \& Bartram CR 2000 Rapid and reliable detection of $\mathrm{N}$-ras mutations in acute lymphoblastic leukemia by melting curve analysis using LightCycler technology. Leukemia 14 312-315.

Nasrin N, Ercolani L, Denaro M, Kong XF, Kang I \& Alexander M 1990 An insulin response element in the glyceraldehyde-3-phosphate dehydrogenase gene binds a nuclear protein induced by insulin in cultured cells and by nutritional manipulations in vivo. PNAS $875273-$ 5277.

Neto ED, Harrop R, Correa-Oliveira R, Wilson RA, Pena SD \& Simpson AJ 1997 Minilibraries constructed from cDNA generated by arbitrarily primed RT-PCR: an alternative to normalized libraries for the generation of ESTs from nanogram quantities of mRNA. Gene 186 135-142.

Nitsche A, Steuer N, Schmidt CA, Landt O \& Siegert W 1999 Different real-time PCR formats compared for the quantitative detection of human cytomegalovirus DNA. Clinical Chemistry 45 1932-1937.

de Noronha CM \& Mullins JI 1992 Amplimers with 3 '-terminal phosphorothioate linkages resist degradation by vent polymerase and reduce Taq polymerase mispriming. PCR Methods and Applications 2 131-136.

Norton DM \& Batt CA 1999 Detection of viable Listeria monocytogenes with a $5^{\prime}$ nuclease PCR assay. Applied and Environmental Microbiology 65 2122-2127.

Oikarinen A, Makela J, Vuorio T \& Vuorio E 1991 Comparison of collagen gene expression in the developing chick embryo tendon and heart. Tissue and development time-dependent action of dexamethasone. Biochimica et Biophysica Acta 1089 40-46.

Oliveira JG, Prados RZ, Guedes AC, Ferreira PC \& Kroon EG 1999 The housekeeping gene glyceraldehyde-3-phosphate dehydrogenase is inappropriate as internal control in comparative studies between skin tissue and cultured skin fibroblasts using Northern blot analysis. Archives of Dermatological Research 291 659-661.

Orlando C, Pinzani P \& Pazzagli M 1998 Developments in quantitative PCR. Clinical Chemistry and Laboratory Medicine 36 255-269.

Overbergh L, Valckx D, Waer M \& Mathieu C 1999 Quantification of murine cytokine mRNAs using real time quantitative reverse transcriptase PCR. Cytokine $\mathbf{1 1}$ 305-312.

Parker RM, Barnes NM 1999 mRNA: detection by in situ and northern hybridization. Methods in Molecular Biology 106 247-283.

Paule MR \& White RJ 2000 Survey and summary: transcription by RNA polymerases I and III. Nucleic Acids Research 28 1283-1298.

Peccoud J \& Jacob C 1996 Theoretical uncertainty of measurements using quantitative polymerase chain reaction. Biophysics Fournal 71 101-108.

Perler FB, Kumar S \& Kong H 1996 Thermostable DNA polymerases. Advances in Protein Chemistry 48 377-435.

Poddar SK, Sawyer MH \& Connor JD 1998 Effect of inhibitors in clinical specimens on Taq and Tth DNA polymerase-based PCR amplification of influenza A virus. Fournal of Medical Microbiology 47 1131-1135.

Puissant C, Bayat-Sarmadi M, Devinoy E, Houdebine LM 1994 Variation of transferrin mRNA concentration in the rabbit mammary gland during the pregnancy-lactationweaning cycle and in cultured mammary cells. A comparison with the other major milk protein mRNAs. European fournal of Endocrinology 130 522-529. 
Raeymaekers L 1993 Quantitative PCR: theoretical considerations with practical implications. Analytical Biochemistry 214 582-585.

Raeymaekers L 1999 General principles of quantitative PCR. In Quantitative PCR Protocols, pp 31-41. Eds B Kochanowski \& U Reischl. Totowa, NJ: Humana Press.

Raff T, van der Giet M, Endemann D, Wiederholt T \& Paul M 1997 Design and testing of beta-actin primers for RT-PCR that do not co-amplify processed pseudogenes. Biotechniques 23 456-460.

Raj GV, Moreno JG, Gomella LG 1998 Utilization of polymerase chain reaction technology in the detection of solid tumors. Cancer 82 1419-1442.

Ramachandran C \& Melnick SJ 1999 Multidrug resistance in human tumors - molecular diagnosis and clinical significance. Molecular Diagnosis 4 81-94.

Rappolee DA, Mark D \& Banda MJ \& Werb Z 1988 Wound macrophages express TGF-alpha and other growth factors in vivo: analysis by mRNA phenotyping. Science 241 708-712.

Reischl U \& Kochanowski B 1999 Quantitative PCR. In Quantitative PCR Protocols, pp 3-30. Eds B Kochanowski \& U Reischl. Totowa, NJ: Humana Press.

Rimarachin JA, Norcross J, Szabo P \& Weksler BB 1992 GAPDH acts as an inducible not constitutive gene in cultured endothelial cells. In Vitro Cellular and Developmental Biology 28A 705-707.

Ripple MO \& Wilding G 1995 Alteration of glyceraldehyde-3phosphate dehydrogenase activity and messenger RNA content by androgen in human prostate carcinoma cells. Cancer Research 55 4234-4236.

Ririe KM, Rasmussen RP \& Wittwer CT 1997 Product differentiation by analysis of DNA melting curves during the polymerase chain reaction. Analytical Biochemistry $245154-160$.

Robinson CA, Hayward-Lester A, Hewetson A, Oefner PJ, Doris PA \& Chilton BS 1997 Quantification of alternatively spliced RUSH mRNA isoforms by QRT-PCR and IP-RPHPLC analysis: a new approach to measuring regulated splicing efficiency. Gene 198 1-4.

Rolland V, Dugail I, Le L, X \& Lavau M 1995 Evidence of increased glyceraldehyde-3-phosphate dehydrogenase and fatty acid synthetase promoter activities in transiently transfected adipocytes from genetically obese rats. Fournal of Biological Chemistry 270 1102-1106.

Rychlik W, Spencer WJ \& Rhoads RE 1990 Optimization of the annealing temperature for DNA amplification in vitro. Nucleic Acids Research 18 6409-6412.

Saccomanno CF, Bordonaro M, Chen JS \& Nordstrom JL 1992 A faster ribonuclease protection assay. Biotechniques 13 846-850.

Scheuermann RH \& Bauer SR 1993 Polymerase chain reactionbased mRNA quantification using an internal standard: analysis of oncogene expression. Methods in Enzymology 218 446-473.

Schittek B, Blaheta HJ, Urchinger G, Sauer B \& Garbe C 1999 Increased sensitivity for the detection of malignant melanoma cells in peripheral blood using an improved protocol for reverse transcription-polymerase chain reaction. British Fournal of Dermatology 141 37-43.

Schutz E \& von Ahsen N 1999 Spreadsheet software for thermodynamic melting point prediction of oligonucleotide hybridization with and without mismatches. Biotechniques 27 $1218-1224$.

Seoh ML, Wong SM \& Zhang L 1998 Simultaneous TD/RTPCR detection of cymbidium mosaic potexvirus and odontoglossum ringspot tobamovirus with a single pair of primers. Fournal of Virological Methods 72 197-204.
Sharma VK, Dean-Nystrom EA \& Casey TA 1999 Semiautomated fluorogenic PCR assays (TaqMan) for rapid detection of Escherichia coli O157:H7 and other Shiga toxigenic E. coli. Molecular and Cellular Probes 13 291-302.

Sheils OM \& Sweeney EC 1999 TSH receptor status of thyroid neoplasms - TaqMan RT-PCR analysis of archival material. Fournal of Pathology 188 87-92.

Shimomaye E \& Salvato M 1989 Use of avian myeloblastosis virus reverse transcriptase at high temperature for sequence analysis of highly structured RNA. Gene Analysis Techniques $625-28$.

Shin JH, Nolte FS, Holloway BP \& Morrison CJ 1999 Rapid identification of up to three Candida species in a single reaction tube by a $5^{\prime}$ exonuclease assay using fluorescent DNA probes. Fournal of Clinical Microbiology 37 165-170.

Siebert PD \& Larrick JW 1993 PCR mimics: competitive DNA fragments for use as internal standards in quantitative PCR. Biotechniques 14 244-249.

Soeth E, Roder C, Juhl H, Kruger U, Kremer B \& Kalthoff H 1996 The detection of disseminated tumor cells in bone marrow from colorectal-cancer patients by a cytokeratin-20specific nested reverse-transcriptase-polymerase-chain reaction is related to the stage of disease. International Fournal of Cancer 69 278-282.

Sokol DL, Zhang X, Lu P \& Gewirtz AM 1998 Real time detection of DNA.RNA hybridization in living cells. PNAS 95 11538-11543.

Sokoloff MH, Tso CL, Kaboo R, Nelson S, Ko J, Dorey F, Figlin RA, Pang S, deKernion J \& Belldegrun A 1996 Quantitative polymerase chain reaction does not improve preoperative prostate cancer staging: a clinicopathological molecular analysis of 121 patients. Fournal of Urology 156 1560-1566.

Souaze F, Ntodou-Thome A, Tran CY, Rostene W \& Forgez P 1996 Quantitative RT-PCR: limits and accuracy. Biotechniques 21 280-285.

Spanakis E 1993 Problems related to the interpretation of autoradiographic data on gene expression using common constitutive transcripts as controls. Nucleic Acids Research 21 3809-3819.

Steuerwald N, Cohen J, Herrera RJ \& Brenner CA 1999 Analysis of gene expression in single oocytes and embryos by real-time rapid cycle fluorescence monitored RT-PCR. Molecular Human Reproduction 5 1034-1039.

de la Taille A, Olsson CA \& Katz AE 1999 Molecular staging of prostate cancer: dream or reality? Oncology 13 187-194.

Thellin O, Zorzi W, Lakaye B, De Borman B, Coumans B, Hennen G, Grisar T, Igout A \& Heinen E 1999 Housekeeping genes as internal standards: use and limits. Fournal of Biotechnology 75 291-295.

Thorpe PH \& Porteous DJ 1999 Rapid quantitation of gene therapy specific CFTR expression using the amplification refractory mutation system. Biotechniques 27 122-126.

Tombline G, Bellizzi D \& Sgaramella V 1996 Heterogeneity of primer extension products in asymmetric PCR is due both to cleavage by a structure-specific exo/endonuclease activity of DNA polymerases and to premature stops. PNAS 93 2724-2728.

Tyagi S \& Kramer FR 1996 Molecular beacons: probes that fluoresce upon hybridization. Nature Biotechnology 14 303-308.

Tyagi S, Landegren U, Tazi M, Lizardi PM \& Kramer FR 1996 Extremely sensitive, background-free gene detection using binary probes and beta replicase. PNAS 93 5395-5400.

Tyagi S, Bratu DP \& Kramer FR 1998 Multicolor molecular beacons for allele discrimination. Nature Biotechnology 16 49-53. 
Vanden Heuvel JP, Tyson FL \& Bell DA 1993 Construction of recombinant RNA templates for use as internal standards in quantitative RT-PCR. Biotechniques 14 395-398.

Vet JA, Majithia AR, Marras SA, Tyagi S, Dube S, Poiesz BJ \& Kramer FR 1999 Multiplex detection of four pathogenic retroviruses using molecular beacons. PNAS 96 6394-6399.

de Vries TJ, Fourkour A, Punt CJ, van de Locht LT, Wobbes T, van den BS, de Rooij MJ, Mensink EJ, Ruiter DJ \& van Muijen GN 1999 Reproducibility of detection of tyrosinase and MART-1 transcripts in the peripheral blood of melanoma patients: a quality control study using real-time quantitative RT-PCR. British Fournal of Cancer $\mathbf{8 0}$ 883-891.

Walker GT, Fraiser MS, Schram JL, Little MC, Nadeau JG \& Malinowski DP 1992 Strand displacement amplification - an isothermal, in vitro DNA amplification technique. Nucleic Acids Research 20 1691-1696.

Wang T \& Brown MJ 1999 mRNA quantification by real time TaqMan polymerase chain reaction: validation and comparison with RNase protection. Analytical Biochemistry 269 198-201.

Wang AM, Doyle MV \& Mark DF 1989 Quantitation of mRNA by the polymerase chain reaction. PNAS $\mathbf{8 6}$ 9717-9721.

Wasserman L, Dreilinger A, Easter D \& Wallace A 1999 A seminested RT-PCR assay for HER2/neu: initial validation of a new method for the detection of disseminated breast cancer cells. Molecular Diagnostics 4 21-28.

Wattjes MP, Krauter J, Nagel S, Heidenreich O, Ganser A \& Heil G 2000 Comparison of nested competitive RT-PCR and real-time RT-PCR for the detection and quantification of AML1/MTG8 fusion transcripts in $\mathrm{t}(8 ; 21)$ positive acute myelogenous leukemia. Leukemia 14 329-335.

Weis JH, Tan SS, Martin BK \& Wittwer CT 1992 Detection of rare mRNAs via quantitative RT-PCR. Trends in Genetics $8263-264$

Winer J, Jung CK, Shackel I \& Williams PM 1999 Development and validation of real-time quantitative reverse transcriptase-polymerase chain reaction for monitoring gene expression in cardiac myocytes in vitro. Analytical Biochemistry 270 41-49.

Winkler A, Mahal B, Zieglgansberger W \& Spanagel R 1999 Accurate quantification of the mRNA of NMDAR1 splice variants measured by competitive RT-PCR. Brain Research Brain Research Protocols 4 69-81.

Wittwer CT \& Garling DJ 1991 Rapid cycle DNA amplification: time and temperature optimization. Biotechniques 10 76-83.

Wittwer CT, Fillmore GC \& Hillyard DR 1989 Automated polymerase chain reaction in capillary tubes with hot air. Nucleic Acids Research 17 4353-4357.

Wittwer CT, Fillmore GC, Garling DJ 1990 Minimizing the time required for DNA amplification by efficient heat transfer to small samples. Analytical Biochemistry $\mathbf{1 8 6}$ $328-331$.

Wittwer CT, Herrmann MG, Moss AA \& Rasmussen RP $1997 a$ Continuous fluorescence monitoring of rapid cycle DNA amplification. Biotechniques 22 130-138.

Wittwer CT, Ririe KM, Andrew RV, David DA, Gundry RA \& Balis UJ $1997 b$ The LightCycler: a microvolume multisample fluorimeter with rapid temperature control. Biotechniques 22 176-181.

Wu DY, Ugozzoli L, Pal BK, Qian J \& Wallace RB 1991 The effect of temperature and oligonucleotide primer length on the specificity and efficiency of amplification by the polymerase chain reaction. DNA and Cell Biology 10 233-238.

Yagi S, Yagi K, Fukuoka J \& Suzuki M 1994 The UAS of the yeast GAPDH promoter consists of multiple general functional elements including RAP1 and GRF2 binding sites. Fournal of Veterinary Medical Science 56 235-244.

Yajima T, Yagihashi A, Kameshima H, Kobayashi D, Furuya D, Hirata K \& Watanabe N 1998 Quantitative reverse transcription-PCR assay of the RNA component of human telomerase using the TaqMan fluorogenic detection system. Clinical Chemistry 44 2441-2445.

Yamada H, Chen D, Monstein HJ \& Hakanson R 1997 Effects of fasting on the expression of gastrin, cholecystokinin, and somatostatin genes and of various housekeeping genes in the pancreas and upper digestive tract of rats. Biochemical and Biophysical Research Communications 231 835-838.

Zamorano PL, Mahesh VB \& Brann DW 1996 Quantitative RT-PCR for neuroendocrine studies. A minireview. Neuroendocrinology 63 397-407.

Zhang J \& Byrne CD 1999 Differential priming of RNA templates during cDNA synthesis markedly affects both accuracy and reproducibility of quantitative competitive reverse-transcriptase PCR. Biochemical Fournal 337 231-241.

Zhang J, Desai M, Ozanne SE, Doherty C, Hales CN \& Byrne CD 1997 Two variants of quantitative reverse transcriptase PCR used to show differential expression of alpha-, betaand gamma-fibrinogen genes in rat liver lobes. Biochemical Fournal 321 769-775.

Zhong H \& Simons JW 1999 Direct comparison of GAPDH, beta-actin, cyclophilin, and 28S rRNA as internal standards for quantifying RNA levels under hypoxia. Biochemical and Biophysical Research Communications 259 523-526.

Zippelius A, Kufer P, Honold G, Kollermann MW, Oberneder R, Schlimok, G, Riethmuller G \& Pantel K 1997 Limitations of reverse-transcriptase polymerase chain reaction analyses for detection of micrometastatic epithelial cancer cells in bone marrow. Fournal of Clinical Oncology 15 $2701-2708$.

RECEIVED 3 February 2000 